\title{
COMPARISON OF THE EFFECTS OF RESISTANCE MODIFIERS ON PROSTATE CANCER, MOUSE LYMPHOMA AND COLON CANCER CELLS
}

\author{
Ph.D. Thesis
}

Ákos Csonka, M.D.

Supervisor: József Molnár, M.D., Ph.D., D.Sc.

Department of Medical Microbiology and Immunobiology Faculty of Medicine

University of Szeged

Szeged

2015 


\section{CONTENTS}

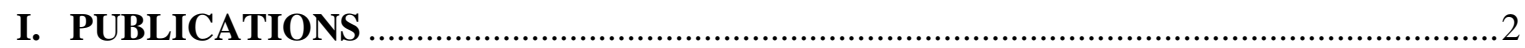

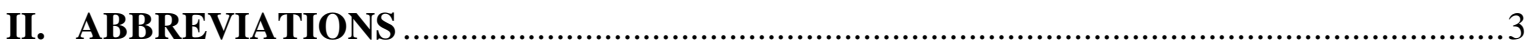

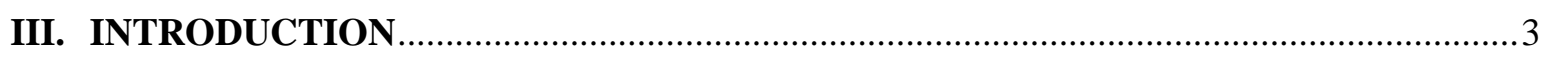

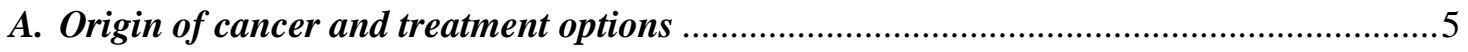

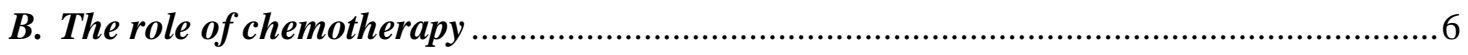

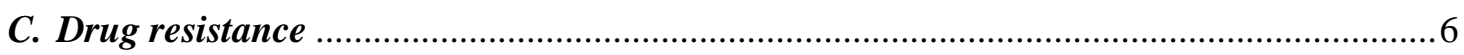

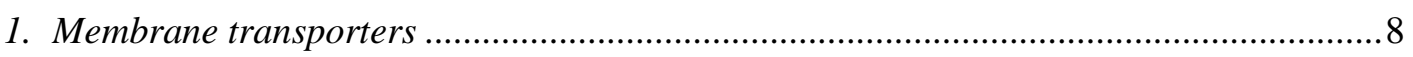

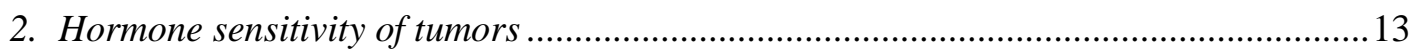

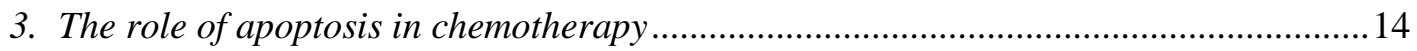

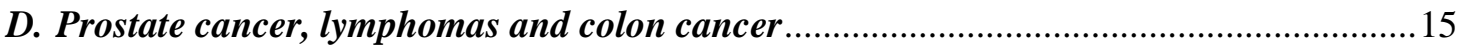

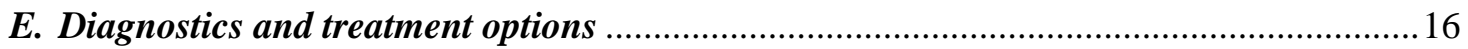

F. New chemotherapeutic approaches to combat MDR tumors ..........................................18

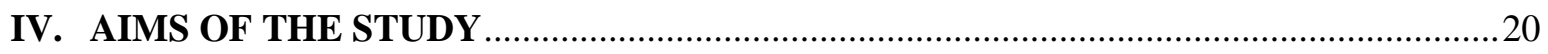

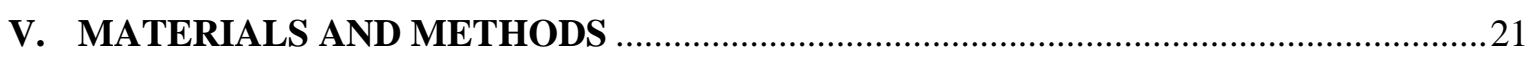

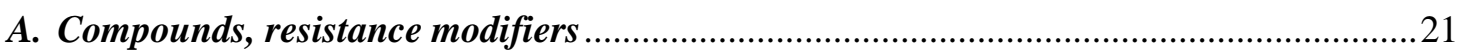

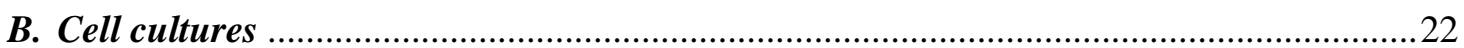

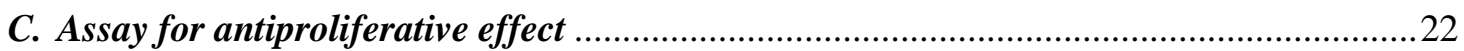

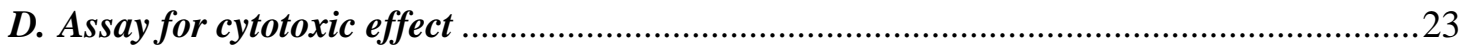

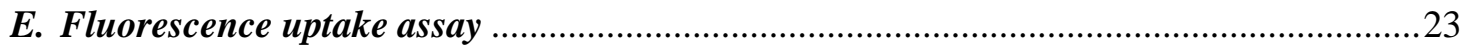

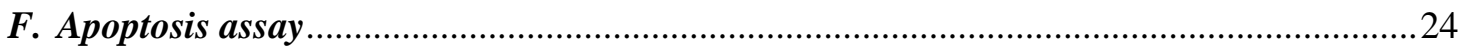

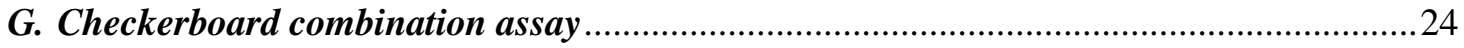

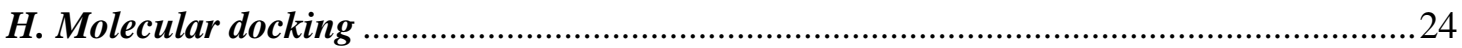

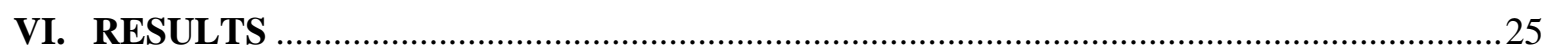

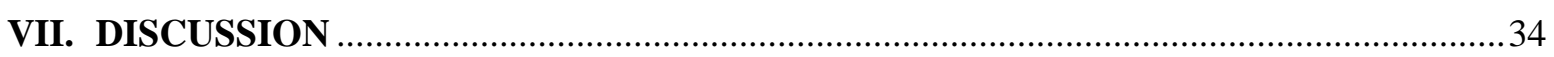

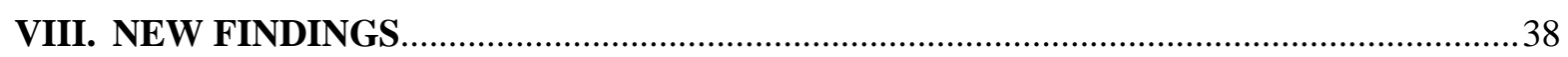

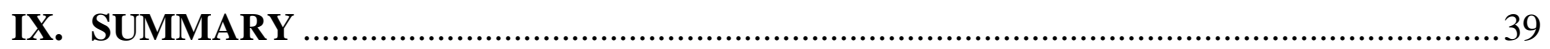

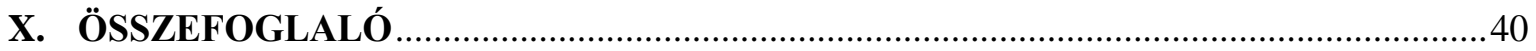

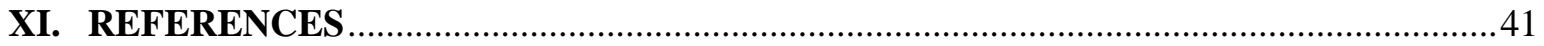

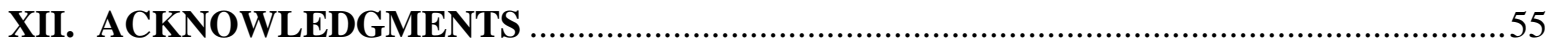

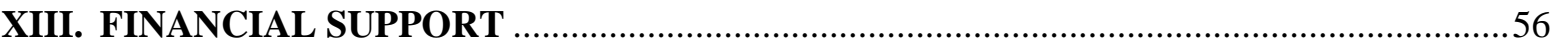

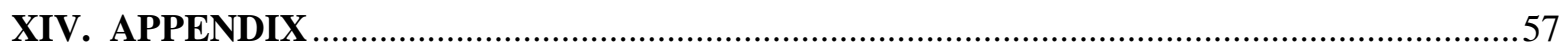

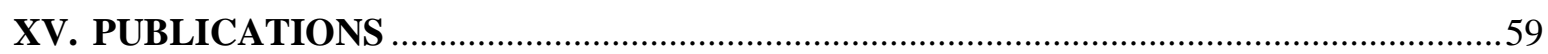




\section{PUBLICATIONS}

\section{A. Publications related to the thesis}

1. Csonka Á, Spengler G, Martins A, Ocsovszki I, Christensen JB, Hendricks O, Kristiansen JE, Amaral L, Molnár J: Effect of thioridazine stereoisomers on the drug accumulation of mouse lymphoma and human prostate cancer cell lines in vitro. In Vivo 27(6): 815-820, 2013. IF:1.148

2. Csonka Á, Hamdoun S, Spengler G, Martins A, Vincze I, Efferth T, Molnár J: Substituted steroidal compounds containing amino- and amido groups reverse multidrug resistance of mouse T-lymphoma and two human prostate cancer cell lines in vitro. Anticancer Research 35(4): 2105-2112, 2015. IF:1.872

3. Takács D, Csonka Á, Horváth Á, Windt T, Gajdács M, Riedl Zs, Hajós Gy, Amaral L, Molnár J, Spengler G: Reversal of ABCB1 related multidrug resistance of colon adenocarcinoma cells by phenothiazines. Anticancer Research 35(6): 3245-3252, 2015. IF:1.872

\section{B. Posters and papers presented at hungarian and international congresses}

1. Csonka Á, Spengler G, Martins A, Ocsovszki I, Chritsten JB, Hendricks O, Kristiansen JE, Amaral L, Molnár J: Anticancer activity of thioridazine stereoisomers. ICACT 2014: $25^{\text {th }}$ International Congress on Anti-Cancer Treatment. Paris, France, 2014.02.042014.02.06. Poster IC/AB1442.

2. Csonka Á, Spengler G, Martins A, Vincze I, Molnár J: Comparison of cytotoxicity of butyloxycarbonyl substituted steroidal compounds on different cancer cell lines in vitro. 9th International Conference of Anticancer Research. Porto Carras, Sithonia, Greece, 2014.10.06-2014.10.10. Poster number 42P. Session: Multidrug and drug resistance. Mechanism and reversal/128.

3. Csonka Á, Spengler G, Martins A, Vincze I, Molnár J: Az amino- és amidocsoportokkal szubsztituált szteroid vegyületek hatása a különböző tumor sejtvonalakon in vitro. Létünk (Újvidék) XLIV:(4) Paper 2014.

4. Spengler G, Mosolygó T, Molnár J, Csonka A, Csonka Á, Amaral L, Burián K: The antichlamydial effect of phenothiazines and disiloxane derivatives. $25^{\text {th }}$ European Congress of Clinical Microbiology and Infectious Diseases, Copenhagen, Denmark, 2015.04.252015.04.28. E-Poster. Session: Antimicrobials: New antimicrobials, ECCMD-1048. 


\section{ABBREVIATIONS}

- AA: amino acids

- ABC: ATP-binding cassette transporter

- ABCB1: ATP-binding cassette transporter B1 subfamily

- Apaf-1: apoptotic protease activating factor-1

- APC: adenomatous polyposis coli tumor suppressor protein

- AR: androgen receptor

- ATP: adenosine triphosphate

- BBB: blood-brain barrier

- Bcl-2: B-cell lymphoma 2

- BCRP-1: breast cancer resistance protein 1

- BOC: tert-butyloxycarbonyl

- CHO: Chinese hamster ovary cells

- CI: combination index

- CNS: central nervous system

- CPBA: chloroperoxybenzoic acid

- CPZ: chlorpromazine

- CRC: colorectal cancer

- CRPC: castration-resistant prostate cancer

- CYP17A1: cytochrome P450c17

- DHT: dihydrotestosterone

- DISC: death-inducing signaling complex

- DMSO: dimethyl sulfoxide

- DNA: deoxyribonucleic acid

- EB: ethidium bromide

- $\mathrm{ED}_{50}$ : effective dose for $50 \%$ inhibition of cell growth

- EDTA: ethylenediaminetetraacetic acid

- FADD: Fas-associated death domain

- FAR: fluorescence activity ratio

- FasL: Fas ligand

- FITC: fluorescein isothiocyanate

- FL: follicular lymphoma

- 5-FU: fluorouracil 
- HRT: hormone replacement therapy

- IARC: International Agency for Research on Cancer

- $\mathrm{IC}_{50 \text { : }}$ calculated concentration of the compound for $50 \%$ inhibition of cell growth

- KLK3: kallikrein-3

- LHRH: luteinizing hormone releasing hormone

- M627: 12H-benzo( $\alpha)$ phenothiazine

- MDR: multidrug resistance

- MDR1: multidrug resistance gene 1

- MRP: multidrug resistance-related protein

- MTT: 3-(4,5-dimethylthiazol-2-yl)-2,5-diphenyltetrazolium bromide

- NHL: non-Hodgkin lymphoma

- OD: optical density

- p53: tumor protein 53

- PAR: parental mouse T-lymphoma cell line

- PBS: phosphate-buffered saline

- PC: prostate cancer

- P-gp: P-glycoprotein

- PI: propidium iodide

- Pki: predicted inhibition constant

- PLGA: polylactic-co-glycolic acid

- PSA: prostate-specific antigen

- QSAR: quantitative structure-activity relationship

- R123: rhodamine 123

- $\mathrm{Rb}$ : retinoblastoma tumor suppressor protein

- R-CHOP: rituximab, cyclophosphamide, adriablastin, vincristine, prednisolone

- RNA: ribonucleic acid

- RP: radical prostatectomy

- SD: standard deviation

- SDS: sodium dodecylsulfate

- SEM: standard error of the mean

- TNF- $\alpha$ : tumor necrosis factor- $\alpha$

- TRAIL: TNF-related apoptosis inducing ligand

- TZ: thioridazine

- WHO: World Health Organization 


\section{INTRODUCTION}

\section{A. Origin of cancer and treatment options}

The data of the International Agency for Research on Cancer (IARC) in 2012 indicated 14.1 million new cancer cases and 8.2 million cancer deaths worldwide annually [1] and, as there is currently a continuous rise, an estimated 22.2 million new cancer cases and 13.2 million cancer deaths will have occurred worldwide by 2030 [2]. The most commonly diagnosed cancers in that report were lung (1.82 million), breast (1.67 million), and colorectal (1.36 million) cancers; the most common causes of cancer death were lung cancer (1.6 million deaths), liver cancer (745,000 deaths), and stomach cancer (723,000 deaths) [1].

In the European Union, a male incidence of 1.4 million and a female incidence of 1.2 million are estimated annually, whereas the numbers of deaths due to cancer are approximately 707,000 for the male, and 555,000 for the female population, the most common types of cancer being: female breast cancer, colorectal cancer, prostate cancer (PC), and lung cancer. These four types represent half of the overall cancer burden in Europe. The most common causes of cancer deaths are lung cancer, colorectal cancer, breast cancer and stomach cancer [3].

The rapid aging of the population makes cancer and its treatment an even more serious issue in Hungary. Like most other European countries, Hungary is experiencing sub-replacement fertility. This is leading to a gradual decline in the number of the population, with a life expectancy of 72.01 years for males and 78.73 years for females in 2013. The mortality rate in Hungary has been dramatically high for a long time, though the data of the Hungarian Central Statistical Office reveal a significantly decrease in the overall yearly number of deaths from 147,000 in the early 1990 s to 127,000 in 2013 [4].

The number of new cancer patients in Hungary increased dramatically in the past century due to aging and the negative impacts of civilization, but it has more or less stabilized annually at around 70,000 in the last 20 years. At present, there are about 300,000 cancer patients, and 32,748 people died from malignant neoplastic diseases in Hungary in 2013, when cancer was the second most frequent cause of death after cardiovascular diseases, with 44,932 deaths [4]. The further aging of the Hungarian population predicted for the next decade is expected to result in a dramatic rise in cancer mortality, and scientific research into novel approaches to cancer treatment is therefore even more urgent. New treatment strategies can target cell-specific markers and signaling pathways or induce the reversal of efflux pump activities. An improved understanding of the molecular mechanisms of cancer progression will promote the development of new therapeutic targets and novel strategies in eradicating cancers. The emergence of new anticancer drugs could not only improve the efficacy of treatment, but also alleviate the side-effects through a more detailed understanding of the mechanism of action [5]. Furthermore, the use of chemopreventive agents could be a promising means of inhibiting carcinogenesis $[6,7,8]$. 


\section{B. The role of chemotherapy}

Apart from the potential surgical removal of a tumor, chemotherapy is the most common treatment of choice in approximately $50 \%$ of all types of cancer [9]. Since the introduction of chemotherapy for cancer treatment, considerable efforts have been made to maximize drug efficacy and minimize the adverse effects $[10,11,12]$. The effectiveness of chemotherapy is a huge concern in medicine. While chemotherapeutic drugs are usually successful in reducing the initial tumor load, their effectiveness is often considerably reduced or even completely lost after a few cycles of treatment. Drug resistance develops, leading to the failure of chemotherapy. Combination chemotherapy for the treatment of resistant cancers was first introduced in 1963 [13, 14, 15]. Not all of the great number of cells that form a neoplasm are in the same development stage or respond in the same way to a given stimulus. In order to prevent the selection of resistant cancer cells, current chemotherapy applies combinations of various drugs to different targets. There are five main families of anticancer drugs [9]:

- Alkylating agents: alkyl groups chemically modify the cellular deoxyribonucleic acid (DNA) and impair its function if attachment occurs to the guanine base of the DNA double-helix strands. Examples of such drugs are cisplatin and ifosfamide. Trough the cross-linking guanine bases in DNA, the DNA strands are unable to uncoil and separate. DNA replication is impaired, and the cell can therefore no longer divide [16].

- Anticancer antibiotics: These agents act through topoisomerase inhibition. Examples are daunorubicin and doxorubicin [17].

- Plant alkaloids: These block cell division by inhibiting the assembly of microtubules due to the central role played by microtubules in a cell, depolymerization of the microtubules and damage to the mitotic spindles, e.g. vinca alkaloids and taxanes [18].

- Antimetabolites: These substances, which are similar in structure to metabolites, stop normal cell development and division by damaging the DNA strand. In fact, antimetabolites are disguised as purines or pyrimidines. The major mechanism of action of these agents is the inhibition of enzymes participating in DNA or ribonucleic acid (RNA) synthesis. Examples are methotrexate and gemcitabine [19].

- Hormones: Hormones can be natural products of an organ or may result from abnormal synthesis, reflecting an unregulated cancer cell metabolism. Drugs such as tamoxifen are antagonists of the estrogen receptor that inhibit the effects of the hormones [20].

\section{Drug resistance}

Drug resistance most probably arises through a selection process, with the emergence of dominant clones from pools of heterogeneous tumor cells [21]. Two types of drug resistance can be distinguished: induced and inherent. Induced drug resistance most obviously presents in a recurrent disease, as a weakened response to a chemotherapy regimen to which the patient 
previously gave a good response. For most chemotherapeutic agents, drug resistance can be stimulated by repeated treatment in tumor cell cultures [22].

Multidrug resistance (MDR) can be divided into two main groups, intrinsic and acquired resistance:

- Intrinsic drug resistance: MDR is not necessarily a result only of treatment of the cells with a drug; moreover, it is related to the type of cell differentiation or the localization of the cells in an organism. The expression intrinsic MDR is applied to cells which are drugresistant even before the drug treatment. As an example, brain tumors are resistant to chemotherapy due to the blood-brain barrier (BBB). Intrinsic MDR may be connected with a genetic change that initiated the tumor.

- Acquired drug resistance can be caused by chemotherapy. Rare genetic variants of drugresistant cells can occur in a tumor cell population under the impact of cytostatic drugs, and these cells can multiply if they have a selective advantage [23, 24].

The main mechanisms of the drug resistance of tumor cells are as follows (Figure 1):

\section{a) Decrease of drug accumulation}

Members of the adenosine triphosphate (ATP)-binding cassette (ABC) transporter family reduce the drug accumulation of the target molecules. Several studies have reported that the MDR gene $1(M D R l)$ encoding human P-glycoprotein (P-gp) and the MDR-related protein gene $(M R P)$ may play a major role in the MDR of breast cancer [25, 26, 27].

\section{b) Drug resistance mediated by detoxification of the drug in the cell}

Glutathione transferases are often up-regulated in tumors, and they have been considered to play a substantial role in MDR in cancer chemotherapy [28, 29].

\section{c) Alterations of drug targets or enhancement of target repair}

Topoisomerase II has been described as the primary cellular target for a number of antitumor drugs which are used in cancer chemotherapy at present. Topoisomerase I has also been identified as the target of camptothecin, an antitumor drug currently under development. Topoisomerases usually solve the topological problems of the DNA which are generated during replication, transcription and recombination, by breaking and rejoining the DNA strands. Alterations of the topoisomerases have been shown to be associated with the development of drug resistance to topoisomerase inhibitors. Reduced gene expression and mutations in the genes are the best-known alterations [30, 31, 32]. 


\section{d) Alterations of genes controlling apoptosis}

Programmed cell death, and particularly the adhesion-dependent regulation of cell survival and apoptosis, is known to be one of the main homeostatic mechanisms whose functions are to control cell positioning, eradicate misplaced cells and hinder metastatic dissemination. Highly metastatic cancer cells demonstrate a higher resistance to programmed cell death as compared with their poorly metastatic counterparts [33]. Whilst studies on B-cell lymphoma 2 (Bcl-2) and tumor protein 53 (p53) established the importance of apoptosis in carcinogenesis, it has subsequently been proved that mutations in many cancer-related genes can interfere with apoptosis. As an example, the Fas/CD95 receptor commonly controls cell numbers in the immune system by eradicating cells through apoptosis, and the disruption of this pathway can result in lymphoproliferative disorders or even cancers [34, 35].

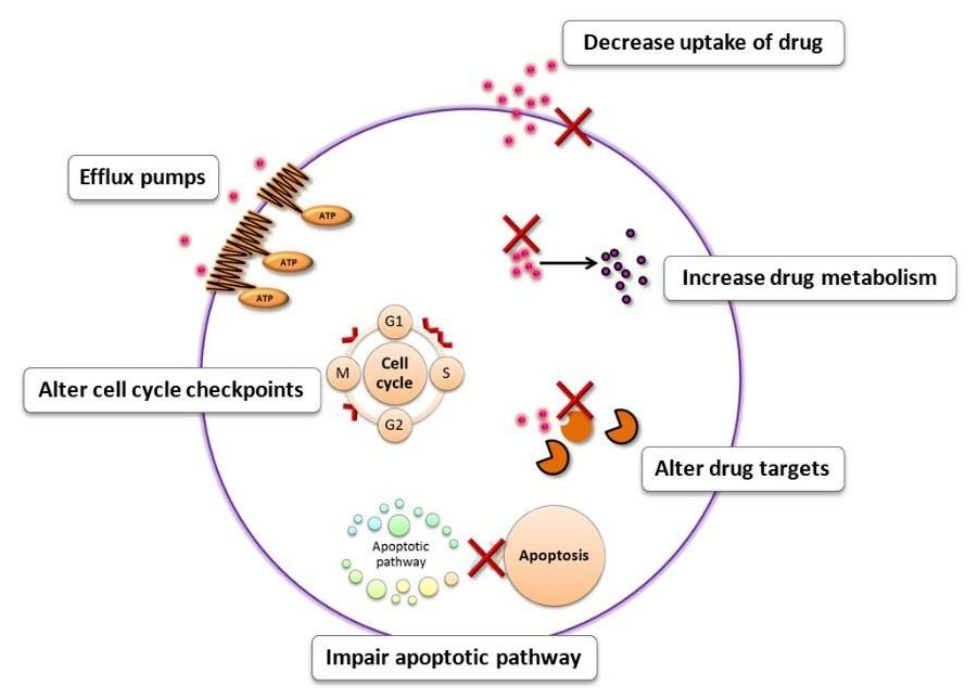

Figure 1. The main mechanisms of the drug resistance of tumor cells [36]

\section{Membrane transporters}

Biological membranes separate specialized functional domains of distinct composition that may persist for the entire life of the cell. Membrane transporters play significant roles in the cell, such as providing nutrients, protecting the cell against harmful agents and establishing electrochemical gradients via the membranes [37].

Efflux pumps are determinants for the absorption, distribution and excretion of drugs, toxic compounds and their metabolites [38]. During evolution, transport pathways emerged that allow molecules such as nutrients and metabolites to pass through the cell membranes. Consequently, the transport of small molecules is mediated by the transmembrane proteins $[39,40]$.

The MDR of tumor cells is frequently associated with the overexpression of membranelocalized $\mathrm{ABC}$ transporters such as $\mathrm{ABCB} 1$ or $\mathrm{P}-\mathrm{gp}$ encoded by the $A B C B 1$ gene. $\mathrm{ABCB} 1$, a 
well-known MDR family member protein, was first characterized in MDR Chinese hamster ovary cells $(\mathrm{CHO})$ by Ling and co-workers [41]. This protein decreases the intracellular concentration of an anticancer drug by eliminating the drug from the cell. In normal tissues, $\mathrm{ABCB} 1$ is localized on the luminal surfaces of the renal tubules, the colon, the small intestine, the bile canaliculi and the vascular epithelia of the brain and spinal cord, and it is associated with physiological functions. $\mathrm{ABCB} 1$ is responsible for the transport of toxic compounds into the cerebrospinal fluid, bile, urine, etc. [42, 43]. Further MDR-related proteins have been discovered in different types of malignancies [44], such as MRPs [45] and breast cancer resistance protein 1 (BCRP-1) [46].

$\mathrm{ABC}$ transporters are transmembrane glycoproteins that promote the unidirectional translocation of structurally unrelated compounds via membrane barriers, utilizing the energy of ATP hydrolysis. The ABC transporter superfamily is one of the largest and oldest protein families with conserved structural features and mechanisms of action, preserved from prokaryotes to humans [47]. The MDR-ABC proteins expel a wide variety of substrates from the cells, including both endo- and xenobiotics. The MDR-ABC transporters also play an essential role in modulating the penetration of small, hydrophobic toxic compounds through physiological barriers, e.g. the gut, BBB, blood-cerebrospinal fluid barrier, blood-testis barrier and feto-maternal barrier [48, 49]. These efflux pumps are also vital in actively expelling toxic metabolites from the liver and the kidneys. When overexpressed in cancer cells, MDR-ABC transporters diminish the intracellular drug concentrations below the effective cytotoxic threshold, which reveals their well-documented role in cross-resistance against structurally unrelated chemotherapeutic agents. To date, at least 12 of the 48 human $\mathrm{ABC}$ proteins have been documented to be partly responsible for the emergence of in vitro MDR [50, 51]. Selection with cytotoxic drugs has been proven to cause the overexpression of endogenous $\mathrm{ABCA} 2, \mathrm{ABCB} 1, \mathrm{ABCC} 1, \mathrm{ABCC} 2, \mathrm{ABCC} 4$ and $\mathrm{ABCG} 2$. Other $\mathrm{ABC}$ transporters, such as ABCB11, ABCC3, ABCC5, ABCC6, ABCC10 and ABCC11, have only been reported to bring about drug resistance when they were engineered to be overexpressed in the model cell lines [48]. The major MDR-ABC proteins that are commonly considered to be responsible for the MDR phenotype of cancer cells are ABCB1/MDR1/P-gp, ABCC1/MRP1 and $\mathrm{ABCG} / \mathrm{BCRP} / \mathrm{MXR} / \mathrm{ABCP}$, each of which has promiscuous and overlapping substrate recognition spectra $[52,53]$. The MDR-ABC proteins require at least two transmembrane domains and two nucleotide binding domains for their appropriate functioning (Figure 2). Full transporters possess all the required domains in a single polypeptide chain, while half-transporters have to homodimerize or heterodimerize to form a functional molecular entity. Transported substrates are bound to the intracellular (most probably intramembrane) high-affinity 'on' sites, and are released at the extracellular 'off' sites. The molecular background of the promiscuous substrate recognition and the molecular events required for generation of the driving force for 
substrate translocation (such as intramolecular movements coupled to ATP hydrolysis and substrate transfer across the lipid bilayer) are still largely unidentified [54, 55]. The distribution of the tissues and the ability of the MDR-ABC transporters to eliminate various structurally and functionally unrelated compounds suggest that the MDR-ABC proteins are involved in a general xenobiotic defense system that has evolved to protect the organism from toxic insults at both cellular and tissue barriers. With regard to the characteristic features shared with the classical immune system, i.e. the recognition and elimination of exogenous molecules invading the body [56], the complex xenobiotic defense machinery has been referred to as the 'chemo-immunity system' $[52,57]$.

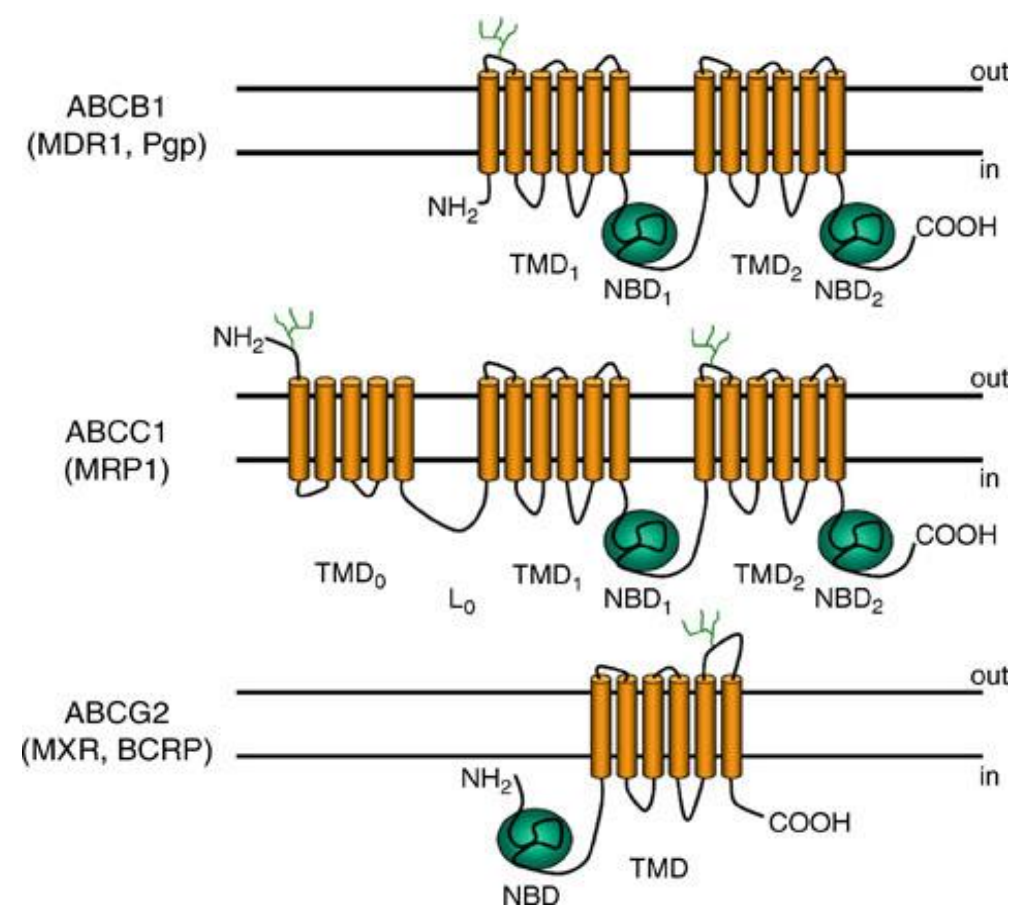

Figure 2. Structures of MDR-ABC transporters [58]

ABCB1 demonstrates a high transport capacity and a wide range of substrate specificity. These transported molecules are generally hydrophobic and amphipathic, uncharged or basic, though negatively charged molecules can also be transported [58].

The most common approach via which to interfere with the overexpressed ABCB1 activity is the use of inhibitors [60]. Three generations of ABCB1 inhibitors have so far been identified and generated. Some ABCB1 substrates and inhibitors are shown in Table I. 
Table I. ABCB1 substrates and inhibitors [61]

\begin{tabular}{|c|c|}
\hline \multicolumn{2}{|c|}{ SELECTED DRUGS OF THE 'CLASSICAL’ MDR SPECTRUM AND 'CLASSICAL' MDR MODULATORS } \\
\hline Drugs transported by MDR1/P-gp & 'Classical' MDR modulators \\
\hline Anthracyclines: daunorubicin, doxorubicin & $\begin{array}{l}\text { Calcium channel blockers: verapamil, nifedipine, } \\
\text { azidopine, dihydropyridines }\end{array}$ \\
\hline $\begin{array}{l}\text { Vinca alkaloids: vinblastine, vincristine, } \\
\text { vindesine }\end{array}$ & $\begin{array}{l}\text { Immunosuppressants and derivatives: cyclosporine A, } \\
\text { valspodar (PSC833), tacrolimus }\end{array}$ \\
\hline Epipodophyllotoxins: etoposide, teniposide & Antiarrhythmics: quinine, quinidine, amiodarone \\
\hline $\begin{array}{l}\text { Antibiotics: actinomycin D, dactinomycin, } \\
\text { mitomycin C }\end{array}$ & Antihypertensives: reserpine, yohimbine \\
\hline Taxanes: paclitaxel & Antibiotics: hydrophobic cephalosporines \\
\hline $\begin{array}{l}\text { Others: colchicine, topotecan, calinomycin, } \\
\text { puromycin, emetine, digoxin, imatinib }\end{array}$ & $\begin{array}{l}\text { Steroid hormones and derivatives: progesterone, } \\
\text { tamoxifen }\end{array}$ \\
\hline $\begin{array}{l}\text { Many other hydrophobic amphipathic drugs and } \\
\text { derivatives }\end{array}$ & $\begin{array}{l}\text { HIV protease inhibitors: sequinavir, indinavir, retanavir } \\
\text { Herbal constituents: curcumin } \\
\text { Others: elacridar (GF120918), zosuquidar (LY35979), } \\
\text { tariquidar (XR9576), laniquidar (R101933) }\end{array}$ \\
\hline
\end{tabular}

It has been established that ABCB1 is capable of interacting with more than 200 compounds, which can be classified on the basis of the transported substrates and the modulators [62, 63, 64]. In cancer cells, ABCB1 is associated with the MDR phenotype, mediating resistance to anthracyclines, vinca alkaloids, colchicine, epipodophyllotoxins and paclitaxel [65]. Thus, the broad spectrum of resistance and the poor prognosis have led to the need to avoid the actions of ABCB1. Broad-spectrum inhibitors appeared in the 1980s and gave rise to some optimism; these molecules could restore some sensitivity to chemotherapy [66]. The use of established drugs in the modulation of the ABCB1 function introduced the first generation of inhibitors [67].

Three generations of compounds have so far been identified and developed as ABCB1 inhibitors, which can also be classified as competitive and noncompetitive inhibitors. As the name implies, the competitive inhibitors compete with the cytotoxic agents for transport. If they are successful, the cytotoxic agent may be transported by the pump, remaining inside the cell. Their noncompetitive counterparts do not compete for the same target. They bind to another target to change the pump conformation, so that the active site is no longer recognized by the substrates [68]. 


\section{- First generation of inhibitors}

These were nonselective and not highly potent, with poor and low binding affinity necessitating high doses to achieve plasma levels sufficient to reverse MDR, and they resulted in unacceptable patient toxicity. They were substrates of $\mathrm{ABCB} 1$, and acted as competitive inhibitors, thereby requiring high serum concentrations of chemosensitizers to produce appropriate intracellular concentrations of the cytotoxic drug, and were therefore unsuccessful in clinical trials [69]. First-generation inhibitors included verapamil, trifluoperazine, cyclosporine-A, quinidine, reserpine, vincristine, yohimbine, tamoxifen and toremifen. Due to the unpredictable pharmacokinetic interactions of these substrates in the presence of chemotherapy agents, novel chemosensitizer analogs were developed with less toxicity and higher potency. Verapamil and tamoxifen were among the best-known ABCB1 modulators, which belong among the first generation of compounds, meaning that they are not specific for ABCB1. Generally, they were less effective and less toxic [70, 71].

\section{- Second generation of inhibitors}

Structural modifications in the first-generation inhibitors led to the development of more potent, second-generation $\mathrm{ABCB} 1$ modulators with a better pharmacological profile, reduced toxicity and better tolerability. They inhibited the metabolism and excretion of cytotoxic agents significantly, leading to unacceptable toxicity, and hence necessitating a reduction of the dose of chemotherapy. Co-administration of these modulators with chemotherapeutic agents resulted in the successful treatment of refractory cancers and the reversal of MDR in clinical trials. The modulators included dexverapamil, dexniguldipine, valspodar (PSC 833) and biricodar citrate (VX-710) [72, 73]. In order to improve the potency, specificity and ABCB1 binding affinity, the use of chemical derivatives of the drugs was introduced as a new approach for the second generation of $\mathrm{ABCB} 1$ inhibitors. They were classified into two categories: analogs of the first generation, e.g. dexverapamil [73], and those with novel chemical structures, e.g. biricodar [74]. As compared with the first generation of inhibitors, the inhibitors of the second generation exhibited a higher ABCB1 inhibitory capacity and fewer toxic side-effects; however, they sometimes proved to participate in unpredictable interactions with anticancer drugs [75].

\section{- Third generation of inhibitors}

These have higher potency and specificity for ABCB1 transporters than the second-generation agents. They do not interfere with cytochrome P450 3A4, and do not affect the drug pharmacokinetics, with no dose alterations in chemotherapy. They include tariquidar (XR9576), zosuquidar (LY335979), laniquidar (R101933), ONT-093 (a substituted diarylimidazole), elacridar (GF120918), OC 144-093, mitotane (NSC-38721), annamycin and $\mathrm{R} 101933$. The most promising one is tariquidar (a nontransported ABCB1 inhibitor), which 
inhibits ATPase by interaction with the protein. It has been investigated in phase III trials for non-small cell lung cancer, but, because of its unfavorable toxicity, it has been suspended. Clinical studies have revealed that tariquidar, LY335979, R101933 and ONT-093 can be administered in therapeutic doses, and minimal interference is observed with the pharmacokinetics of cytotoxic agents. They have revealed promising results in clinical trials, and the further development of these agents may establish the true therapeutic potential of ABCB1-mediated MDR reversal [76]. Tariquidar, a third-generation inhibitor with none of the limitations of the first- and second-generation inhibitors, has the highest specificity, inhibiting ABCB1 both specifically and potently. Inhibition of the ATPase activity of ABCB1 suggests that the modulating effect stems from the inhibition of substrate binding, the inhibition of ATP hydrolysis and/or both [77]. Clinical trials of third-generation inhibitors [78] have demonstrated the better tolerability of tariquidar, with no significant pharmacokinetic interaction with chemotherapy, which have made it an ideal agent for the identification of ABCB1 inhibition activity in cancer. The targeted delivery of paclitaxel and tariquidar co-encapsulated in biotinfunctionalized polylactic-co-glycolic acid (PLGA) nanoparticles confirmed its significantly stronger cytotoxicity in vitro and higher tumor growth inhibition in vivo in drug-resistant tumor mouse models as compared with paclitaxel nanoparticles alone [79]. As concerns the strategies used in the third generation of compounds, the aim is to overcome the toxicity observed with the previous generations and to improve the pharmacokinetic interactions of the compounds. The new tools that are now available, such as computational chemistry or molecular pharmacology, have been fundamental in shifting the approach of blind screening to rational drug design. These new tools, together with quantitative structure-activity relationships (QSARs), have proved very helpful in the discovery of new compounds, such as GF120918 (Elacridar) [80, 81].

\section{Hormone sensitivity of tumors}

The androgen receptor (AR) is expressed in many cell types and androgen/AR signaling has been identified as playing an essential role in modulating carcinogenesis and metastasis in many cancer types, including prostate, bladder, kidney, lung, breast and liver cancers. Thus, better therapeutic approaches may be developed by targeting the AR or its downstream signaling in individual cell types, providing a chance to combat these hormone-related tumors in various stages more successfully $[82,83]$.

Since the pioneering work of Huggins et al., a number of researchers have studied the role of androgens in the maintenance of the prostate structure, its development and growth, and the stimulation of PC cells [84]. AR is a central mediator of androgen action in all tissues that are androgen-responsive, but the role of AR can be paradoxical as it has both stimulatory and antiproliferative actions, which depend on the microenvironment and hormone levels [82]. 
The experiments of Cavalieri and Rogan on the estrogen metabolism, the formation of DNA adducts, mutagenicity, cell transformation and carcinogenicity resulted in the hypothesis that the reactions of specific estrogen metabolites, and especially the electrophilic catechol estrogen-3,4quinones, with DNA can generate the critical mutations to lead to the development of breast cancer and also other human cancers. Men with prostate cancer or non-Hodgkin lymphoma (NHL) also have high levels of estrogen-DNA adducts in their urine. The formation of estrogenDNA adducts may therefore play an important role in the etiology of NHL $[85,86]$.

On the basis of both animal and human data, hormone replacement therapy (HRT) is classified as a Group 1 carcinogen by the IARC [87]. Estrogen is also known to have immunomodulatory effects [88], and NHL is a tumor the development of which is sensitive to immunological function [89]. Animal studies have clearly shown that estrogen administration induces endometrial, breast and ovarian tumors, and there are significant data revealing that estrogen can also result in the development of a lymphoma [90]. HRT is associated with a substantially increased risk of endometrial cancer and a moderately elevated risk of breast cancer in humans when estrogen is unopposed by progestins [91]. HRT also appears to be associated with a mild risk of colorectal cancer (CRC), whereas data on ovarian, liver and thyroid cancers and cutaneous melanoma are equivocal or indicate no association [91].

$\mathrm{CRC}$ is generally not considered to be a hormone-related malignancy; nevertheless, evidence is accumulating to suggest that sex hormones may play a role in its development $[92,93,94]$. The hormone precursor progastrin is now recognized as a growth factor that has an important role in colon carcinogenesis $[95,96]$. The role of progastrin in the proliferation, survival and migration of human colon cancer cells has also been clearly established [97, 98, 99]. The growth-promoting effects of progastrin are mediated through the activation of several key signal transduction pathways $[100,101]$. Moreover, several publications have shown that the depletion of endogenous progastrin produced by colon cancer cells leads to an inhibition of tumor growth [102, 103].

\section{The role of apoptosis in chemotherapy}

Programmed cell death is defined as regulated cell death mediated by an intracellular program. It has a basic function in the evolution of organs, homeostasis and cancer. Apoptosis is one of the major types of cell death, characterized by special cell morphology and pathways. The discovery of important interconnections between the apoptotic cell death mediators and signaling pathways has shed light on novel options in the targeted treatment of cancer [104]. Apoptosis is characterized by cell membrane blebbing, cell shrinkage, nuclear fragmentation, chromatin condensation, and chromosomal DNA fragmentation [105, 106]. There are two basic apoptotic signaling pathways: the extrinsic pathway and the intrinsic pathway [107]. 
Various intracellular stimuli can activate the intrinsic pathway, including DNA damage, growth factor deprivation and oxidative stress. It relies on the formation of a complex called the apoptosome, which is composed of procaspase-9, apoptotic protease activating factor-1 (Apaf-1), and cytochrome c. Genomic stability depends on an efficient DNA damage repair system to keep the chromosomes intact. Unrepaired DNA damage not only causes cell cycle arrest, but can also lead to apoptotic cell death [108]. The removal of some specific proteins from the nucleus is important in the regulation of the cell cycle and in the proliferation of both normal and malignant tissues [109, 110]. Examples of nuclear effectors which are exported into the cytoplasm in cancer include the drug targets topoisomerase II $\alpha$ [111], BCR-ABL [112] and tumor suppressor proteins such as Rb [113], APC [114], p53 [115], p21 [116] and p27 [117]. This makes nuclear export inhibition a potential target for therapeutic intervention in cancer [118, 119].

The extrinsic pathway of apoptosis is initiated by the binding of death ligands, e.g. the Fas ligand (FasL), the TNF-related apoptosis inducing ligand (TRAIL), and tumor necrosis factor- $\alpha$ (TNF- $\alpha$ ), to death receptors of the TNF receptor superfamily. This is followed by the assembly of the death-inducing signaling complex (DISC), which consists of the Fas-associated death domain (FADD) protein and procaspase-8/10 [120]. Cell survival also depends on the preservation of mitochondrial integrity, controlled by a well-balanced transaction between antiand pro-apoptotic Bcl-2 family members. Their frequent deregulation plays a significant role in human pathologies inclusive of autoimmunity or cancer [121].

\section{Prostate cancer, lymphomas and colon cancer}

$\mathrm{PC}$ is a serious multidimensional disorder that arises because of the misrepresentation of signaling cascades and acquired resistance against apoptosis. It is progressively becoming increasingly insurmountable because of the rheostat-like switching of oncogenic signaling in an androgen-dependent and androgen-depleted microenvironment [122]. PC is related to age, and is currently being diagnosed with increasing incidence and prevalence rates as a consequence of the increase in life expectancy and the better diagnostic techniques [123]. PC has become the most common noncutaneous malignant disease in men, and the second leading cause of male cancer deaths in the USA. In the EU, PC is the most common cancer in men, and more than 417,000 new cases are diagnosed each year. Because of the growth of the global population and their aging, the PC burden is expected to grow to 1.7 million new cases and around 500,000 new deaths annually worldwide by 2030 [3]. The mortality rate of PC is increasing disproportionately with the aging of the male population within an overall population growth, and the explanation for this alarming trend is still unavailable [124]. In Hungary, for example, 3406 new cases were reported in 2010, and approximately 1250 men die from PC each year $[125,126]$. 
The morbidity and mortality rates of lymphoproliferative diseases are significant even currently as 450,000 new cases and 225,000 deaths are reported worldwide annually [1]. These diseases are quite heterogeneous; accordingly, besides the classical morphological histology, immunophenotyping, the identification of cytogenetic, molecular characteristics and an overall assessment of the clinical features are essential for establishing the exact diagnosis. The currently used 2008 classification of the World Health Organization (WHO) incorporates all the available information [127].

Nevertheless, novel and highly precise molecular biological techniques have been developed and have recently become available for laboratories in hematopathology and molecular genetics departments. They include the microarray techniques and the next-generation sequencing procedure, which may prove the complexity and/or heterogeneity of lymphomas and may help promote an understanding of the development of certain lymphoma subtypes [128].

$\mathrm{CRC}$ is the third most common type of cancer and the fourth most common cancer cause of death globally, resulting in approximately 1.2 million new cases of cancer morbidity and 600,000 cases of mortality annually [1]. The incidence is low in those under the age of 50 years, but it increases markedly with age. The average age at diagnosis in the developed countries is about 70 years [128]. The highest incidence is reported in countries of Europe, North America and Oceania, and the lowest incidence in some countries in South and Central Asia and Africa [130]. However, a rapid increase has recently been recorded in previously low-risk countries, such as Spain and several countries in Eastern Europe and East Asia, which may possibly be due to changes in diet and the risk factors of the western lifestyle [131]. However, in the USA and several other highincome countries, the incidence has leveled off or has started to decrease, probably because of the widespread use of sigmoidoscopy and colonoscopy with polypectomy [130, 132].

\section{E. Diagnostics and treatment options}

The current diagnosis of PC is based on the level of the prostate-specific antigen (PSA). PSA, also known as gamma-seminoprotein or kallikrein-3 (KLK3), is a glycoprotein enzyme encoded in humans by the KLK3 gene. PSA, a member of the KLK-related peptidase family, is secreted by the epithelial cells of the prostate gland. PSA is present in small quantities in the serum of men with healthy prostates, but it is often elevated in the presence of PC or other prostate disorders [133]. Since the PSA test is used for diagnosis, PC is detected in more localized and/or early stages. Nevertheless, PC recurs in $10-40 \%$ of the cases, requiring further treatment that depends on the differentiation stage. When hormonal therapy fails, and the disease progresses to a castration-resistant stage, chemotherapy should be considered [134, 135].

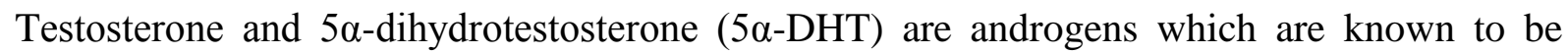
required for the development of both the normal prostate and PC. The high-affinity binding of 
DHT to the AR initiates the androgen-dependent gene activation that is required for normal prostate development, and it influences the growth of prostate tumors [136]. Drugs that target the backdoor pathway of DHT synthesis provide an opportunity to enhance the clinical response to luteinizing hormone releasing hormone (LHRH) agonists or antagonists, AR antagonists, and inhibitors of $5 \alpha$-reductase (finasteride or dutasteride), and other steroid metabolism enzyme inhibitors (ketoconazole or the recently available abiraterone acetate) [137, 138]

Neoadjuvant systemic therapy before radical prostatectomy (RP) is a plausible option to augment treatment outcomes for men with clinically localized high-risk PC. Other new agents are currently being studied, such as those targeting the vascular endothelial growth factor receptor, epidermal growth factor receptor, platelet-derived growth factor receptor, clusterin and immunomodulatory therapeutics [139].

The state of the art treatment of lymphomas has been promoted by the developing knowledge in molecular genetics. The currently available knowledge provides the potential for targeted therapeutic options besides establishing the correct diagnosis. These options comprise monotherapy or combinations with each other and/or with the traditional chemotherapeutic protocol, thereby enhancing the efficacy of the therapy and the survival rate, as already proven by administration of the first biomarker therapy in cancer patients, the R-CHOP drug combination (rituximab, cyclophosphamide, adriablastin, vincristine and prednisolone), in follicular lymphoma (FL) and diffuse large B-cell lymphoma [140].

$\mathrm{CRC}$ is a heterogeneous disease. It can vary as concerns its clinical presentation, molecular characteristics and the prognosis of the patient. The response to therapy also displays a diverse pattern in cancer patients [141, 142]. One key element through which to decrease the risk of CRC might be the early diagnosis established by colonoscopy and treatment of the precancerous lesions [143]. Cancer-derived DNA may arise in the periphery, either by the direct shedding of tumor-derived DNA into the surrounding tissues or by the apoptosis of circulating tumor cells. DNA methylation biomarkers can be tested in various bodily fluids to detect this free-floating DNA. The stools are a suitable bodily medium for analysis for colon cancer [144]. The present treatment for $\mathrm{CRC}$ is based on combination therapy, which may involve surgery, local radiotherapy and/or chemotherapy. 5-Fluorouracil (5-FU) combined with leucovorin and irinotecan is currently the recommended first-line chemotherapy for CRC. Further commonly administered compounds include capecitabine, a more convenient alternative to intravenous infusions of 5-FU for patients who tolerate oral chemotherapy, and platinum-based drugs, such as oxaliplatin and cisplatin $[145,146,147]$. 


\section{G. New chemotherapeutic approaches to combat MDR tumors}

Cancer cells rapidly develop several defense mechanisms to prevent the effects of chemotherapy. Cancer cells can metabolize drugs differently from their normal counterparts, and this should be considered not only during the initial treatment, but also in the development of resistance [148]. There is therefore a constant need to discover new, effective chemotherapeutic compounds.

\section{- $\underline{\text { Steroids }}$}

Steroids are derivatives of the triterpenoid squalene, which contain three fused cyclohexane rings and a cyclopentane ring. The methyl groups are usually present on C-10 and C-13. An alkyl side-chain may also be present on C-17. Sterols are steroids carrying a hydroxy group on C-3 and most of the skeleton of cholestane. Additional carbon atoms may also be present in the side-chain [149]. Steroids and their metabolites often function as signaling molecules. The most notable examples are steroid hormones. Steroids along with phospholipids function as components of cell membranes. Steroids such as cholesterol decrease the fluidity of the membrane. Similarly to lipids, steroids represent highly concentrated energy stores. However, steroids are not typically used as sources of energy, they are normally metabolized and excreted. Steroids constitute an extensive and important class of biologically active compounds that are widely used to treat a variety of conditions such as cancers, infections and autoimmune diseases. The majority of PC cases are diagnosed as a localized disease. Definitive treatment, active surveillance or watchful waiting are employed as therapeutic paradigms. The current standard of care for the treatment of metastatic PC is either medical or surgical castration. Once PC progresses in spite of castrate androgen levels, it is defined as 'castration-resistant prostate cancer' (CRPC). Patients may even have elevated PSA levels with possible bone, lymph node or solid organ metastases. Docetaxel was the only agent approved for the treatment of CRPC in 2010. It is now known that cells from patients with CRPC express ARs and remain continuously influenced by androgens. New hormonal therapies that specifically target the biochemical conversion of cholesterol to testosterone have come to the forefront. The use of the cytochrome P450c17 (CYP17A1) inhibitor underlies one of the most recent advances in the treatment of CRPC. Abiraterone acetate was the first CYP17A1 inhibitor approved in the USA. The CYP17A1 inhibitors orteronel, galeterone, VT-464 and CFG920 have recently been identified [150]. The biologically active form of vitamin $\mathrm{D}_{3}, 1 \alpha, 25$-dihydroxyvitamin $\mathrm{D}_{3}$, has several antitumor properties, such as antiproliferative and prodifferentiating effects, and also effects on the invasion, metastasis and angiogenesis of tumors [151]. 


\section{- Phenothiazines}

Phenothiazines, which are nitrogen- and sulfur-containing tricyclic compounds, were identified more than a hundred years ago. The parent compound, 10H-dibenzo-1,4-thiazine, was first obtained by Bernthsen in 1883 . Over 5000 phenothiazine derivatives have been prepared to date and this class of organic compounds has become increasingly more important due to their varied significant biological and chemical properties. Phenothiazines, and mostly substituted with dialkylaminoalkyl groups at position 10 and additionally with small groups at position 2, have valuable activities such as neuroleptic, antiemetic, antihistaminic, antipuritic, analgesic and antihelmintic activities too [152]. At least 100 phenothiazines have been used in therapy, mainly as neuroleptics. Recent reports have described promising anticancer, antibacterial, antiplasmid and MDR reversal activities of classical phenothiazines [153, 154, 155, 156]. Phenothiazines are relatively inexpensive, widely available, well-tolerated and nontoxic compounds [157]. Phenothiazines have been demonstrated to have neuroleptic, antimycobacterial and anticancer properties $[158,159]$. Chlorpromazine (CPZ) has been shown to inhibit the growth of cancer cells $[159,160]$. Other phenothiazines, such as promethazine [161] and thioridazine (TZ) [162, 163], also inhibit a variety of cancer types. In fact, the properties of phenothiazines that are associated with inhibitory effects on cancer cell growth can be reproduced with inhibitors of calmodulin [164, 165]. Calcium signaling pathways and calcium-dependent enzymes have been suggested as targets of phenothiazines [166]. Since some of these pathways are involved in the generation of ATP, and ATP is needed for the activity of $\mathrm{ABC}$ transporters, which, when overexpressed, result in the MDR phenotype of cancer cells, it is obvious that studies focusing on the activity of phenothiazines toward the ABC transporters of cancer cells should be performed. TZ is much milder and produces fewer unfavorable side-effects than CPZ [166], and the activity of this phenothiazine has therefore been studied on the viability of MDR mouse lymphoma cells transfected with the human $A B C B 1$ gene, which codes for $\mathrm{ABCB} 1$, the transporter that, when overexpressed, renders the cell immune to anticancer agents $[167,168]$, and additionally on the activity of the ABCB1 transporter itself [169]. Phenothiazines belong among the oldest, synthetic antipsychotic drugs, which do not have precursors in the world of natural compounds. Apart from their basic neuroleptic action related to the blockade of dopaminergic receptors, phenothiazine derivatives can also perform diverse biological activities, which are responsible for their cancer chemopreventive effect, such as calmodulin and protein kinase $\mathrm{C}$ inhibitory actions, an antiproliferative effect and inhibition of the P-gp transport function [170]. 


\section{AIMS OF THE STUDY}

The aim of our study was to examine new perspectives of chemotherapy in connection with modification of the MDR of cancer with the intention of finding nontoxic and effective MDR reversal agents among substituted steroids and phenothiazines. The activities of selected MDR reversal compounds were examined in combination with anticancer chemotherapeutics in different cancer models in vitro. Apoptosis induction and the inhibition of tumor promotion were investigated in mouse T-lymphoma and prostate cancer models.

The main goals of the study:

- To establish the antiproliferative effects of potential resistance modifiers by MTT assay on the L5178 mouse T-lymphoma parental cell line (PAR) and its L5178Y human ABCB1gene transfected subline (MDR), the LNCaP and PC3 prostate cancer cell lines and the MDR Colo 320 colon adenocarcinoma cancer cell line

- To determine the cytotoxic effects of potential resistance modifiers by the 3-(4,5dimethylthiazol-2-yl)-2,5-diphenyltetrazolium bromide (MTT) assay on the PAR and MDR mouse T-lymphoma cell lines

- To investigate the reversal of MDR by steroid derivatives and TZ on ABCB1-related resistance by means of flow cytometry, using rhodamine 123 (R123) accumulation assay on the MDR mouse T-lymphoma cell line

- To study the interactions of anticancer drugs with steroid and $N$-hydroxyalkyl-2aminophenothiazine resistance modifiers by using an in vitro model for combination chemotherapy by a checkerboard microplate method in PC3 and MDR colon adenocarcinoma Colo 320 cells, respectively

- To determine the apoptosis induction of selected steroid and TZ resistance modifiers through Annexin V-FITC assays, using flow cytometry in the MDR mouse T-lymphoma and PC3 prostate cancer cell lines

- To evaluate the structure-activity relationships of steroid derivatives, with docking calculations based upon biological studies

- To identify the role of TZ stereoisomers in the anticancer activity through use of the MDR mouse T-lymphoma cancer model 


\section{MATERIALS AND METHODS}

\section{A. Compounds, resistance modifiers}

Verapamil, phosphate-buffered saline (PBS), dimethyl sulfoxide (DMSO), MTT, sodium dodecylsulfate (SDS), R123, propidium iodide (PI) and ethidium bromide (EB) were purchased from Sigma-Aldrich (St Louis, MO, USA). Doxorubicin hydrochloride was from Teva Pharma Kft. (Budapest, Hungary).

Aminosteroids 14 and 15 were prepared from oximes of the corresponding ketosteroids by sodium tetrahydroborate reduction in the presence of $\mathrm{NiCl}_{2}$, as described previously [171]. The aminosteroids obtained were acylated with $N$-tert-butyloxycarbonyl (BOC)-protected amino acids by a mixed anhydride method (1-5), and the protecting group was eliminated with dry hydrogen chloride in dioxane solution, affording amine hydrochlorides 6-12. Alkylaminomethylene steroids were prepared from 16-hydroxymethylene-17-ketosteroids and primary amines and acetylated with acetic anhydride (16-20) [172, 173]. The D-condensed heterocyclic steroid 21 was prepared from 16-hydroxymethylene-3-methoxyestra-1,3,5(10)trien-17-one with guanidine [174, 175]. The 16-aminomethyl-androstene derivative 13 was synthesized from the corresponding 16-methylene-17-ketone by addition of $n$-propylamine and selective $O, O$-desacetylation of the fully acetylated product [175]. The chemical structures of the steroid derivatives evaluated in this study are shown in Annex 1. Samples of the abovementioned compounds were dissolved in DMSO as $2.0 \mathrm{mg} / \mathrm{mL}$ stock solutions. $\mathrm{N}$-BOC-isoleucine- $\mathrm{O}$-pentachlorophenyl ester (23) was obtained from Sigma-Aldrich (St. Louis, MO, USA).

TZ hydrochloride is a racemic mixture of enantiomers with an asymmetric carbon at position 2 in the piperidyl ring. The racemic TZ was purchased from Sigma-Aldrich (Vallensbak Strand, Denmark). TZ in its ordinarily clinically prescribed form is a racemic mixture of equal amounts of the (+) and (-) enantiomers (Annex 2). The enantiomers were separated by resolution of the commercially available TZ racemate according to a reported procedure [176].

The chemical structures of the 26 tested $N$-hydroxyalkyl-2-aminophenothiazine derivatives are shown in Annex 3 [177]. The compounds were prepared by recently elaborated chemical transformations [178]. Thus, 1a-o were obtained by protection and Buchwald-Hartwig amination of $\mathbf{1}, \mathrm{R}=\mathrm{Cl}$, whereas $\mathbf{2}$ was obtained as a by-product of the hydroboration-oxidation transformation of the appropriately substituted dienylphenothiazine. Sulfoxides 3a-e and sulfones $\mathbf{3 f}-\mathbf{j}$ were prepared by oxidation of the related phenothiazine $\mathbf{1}$ with $m$-chloroperoxybenzoic acid ( $m$-CPBA). The $N$-hydroxyalkyl-2-aminophenothiazine derivatives were dissolved in DMSO. 


\section{B. Cell cultures}

The L5178 mouse T-cell lymphoma cells (PAR) (ECACC Cat. No. 87111908, obtained from FDA, Silver Spring, MD, USA) were transfected with $\mathrm{pHa}$ MDR1/A retrovirus, as previously described by Cornwell et al. [179]. The ABCB1-expressing cell line L5178Y (MDR) was selected by culturing the infected cells with colchicine. L5178 (parent) mouse T-cell lymphoma cells and the L5178Y human ABCB 1-transfected subline were cultured in McCoy's 5A medium supplemented with $10 \%$ heat-inactivated horse serum, $200 \mathrm{mM} \mathrm{L-glutamine}$ and a penicillinstreptomycin mixture in concentrations of $100 \mathrm{U} / \mathrm{L}$ and $10 \mathrm{mg} / \mathrm{L}$, respectively.

The prostate cancer cell lines: hormone-resistant PC3 (ATCC ${ }^{\circledR}$ Cat. No. CRL-1435) and the hormone-sensitive LNCaP (ATCC ${ }^{\circledR}$ Cat. No. CRL-1740) were grown in RPMI-1640 medium with $2 \mathrm{mM}$ L-glutamine and $10 \%$ fetal bovine serum supplemented with antibiotics. Adherent human cancer cells were detached with $0.25 \%$ trypsin and $0.02 \%$ ethylenediaminetetraacetic acid (EDTA) for $5 \mathrm{~min}$. The cell lines were incubated in a humidified atmosphere $\left(5 \% \mathrm{CO}_{2}, 95 \%\right.$ air $)$ at $37^{\circ} \mathrm{C}$.

The human colon adenocarcinoma cell lines, the Colo 205 doxorubicin-sensitive parent and Colo 320/MDR-LRP resistant to anticancer agents expressing ABCB1 (MDR1)-LRP, ATCC ${ }^{\circledR}$ Cat. No. CCL-220.1 (Colo 320) and ATCC ${ }^{\circledR}$ Cat. No.CCL-222 (Colo 205), were purchased from LGC Promochem (Teddington, England). The cells were cultured in RPMI 1640 medium supplemented with $10 \%$ heat-inactivated fetal bovine serum, $2 \mathrm{mM}$ L-glutamine, $1 \mathrm{mM} \mathrm{Na}$ pyruvate and $100 \mathrm{mM}$ Hepes. The cell lines were incubated in a humidified atmosphere $(5 \%$ $\mathrm{CO}_{2}, 95 \%$ air) at $37^{\circ} \mathrm{C}$. The semi-adherent human colon cancer cells were detached with $0.25 \%$ trypsin and $0.02 \%$ EDTA for $5 \mathrm{~min}$ at $37^{\circ} \mathrm{C}$.

\section{Assay for antiproliferative effect}

The effects of increasing concentrations of compounds on cell growth were determined in 96well flat-bottomed microtiter plates. The compounds were serially diluted in $100 \mu \mathrm{L}$ of McCoy's 5A or RPMI-1640 medium. $6 \times 10^{3}$ mouse T-cell lymphoma cells (PAR or MDR), $5 \times 10^{3}$ human colonic adenocarcinoma cells (Colo 205 or Colo 320 ) in $50 \mu \mathrm{L}$ of medium or $1 \times 10^{4} \mathrm{PC} 3$ prostate cancer cells in $100 \mu \mathrm{L}$ of medium were then added to each well, with the exception of the medium control wells. The culture plates were further incubated at $37{ }^{\circ} \mathrm{C}$ under $5 \% \mathrm{CO}_{2}$ for $72 \mathrm{~h}$. At the end of the incubation period, 15 or $20 \mu \mathrm{L}$ of MTT solution (from a $5 \mathrm{mg} / \mathrm{mL}$ stock) was added to each well and, after another $4 \mathrm{~h}, 100 \mu \mathrm{L}$ of $10 \%$ SDS in 0.01 $\mathrm{N} \mathrm{HCl}$ was measured into each well. The culture plates were further incubated at $37{ }^{\circ} \mathrm{C}$ overnight. The cell growth was determined by measuring the optical density (OD) at $540 \mathrm{~nm}$ (ref. $630 \mathrm{~nm}$ ) with a Multiscan EX ELISA reader (Thermo Labsystem, Cheshire, WA, USA). In the assay, the solvent did not have any effect on the cell growth at the concentrations used for half-maximal inhibitory concentration $\left(\mathrm{IC}_{50}\right)$ calculations. $\mathrm{IC}_{50}$ values and the standard error 
of the mean (SEM) of triplicate experiments were calculated by using GraphPad Prism software version 5.00 for Windows with nonlinear regression curve fit (GraphPad Software, San Diego, CA, USA; www.graphpad.com).

\section{Assay for cytotoxic effect}

The effects of increasing concentrations of the drugs alone on cell growth were tested in 96-well flat-bottomed microtiter plates. The compounds were diluted in $100 \mu \mathrm{L}$ of medium. $2 \times 10^{4}$ mouse T-cell lymphoma cells (PAR or MDR) in $50 \mu \mathrm{L}$ of medium were then added to each well, with the exception of the medium control wells. The culture plates were further incubated at $37^{\circ} \mathrm{C}$ for $24 \mathrm{~h}$; at the end of the incubation period, $15 \mu \mathrm{L}$ of MTT solution (from a $5 \mathrm{mg} / \mathrm{mL}$ stock) was added to each well. After incubation at $37{ }^{\circ} \mathrm{C}$ for $4 \mathrm{~h}, 100 \mu \mathrm{L}$ of SDS solution (10\% in $\left.0.01 \mathrm{M} \mathrm{HCI}\right)$ was added to each well and the plates were further incubated at $37^{\circ} \mathrm{C}$ overnight. The cell growth was determined by measuring the OD at $540 \mathrm{~nm}$ (ref. $630 \mathrm{~nm}$ ) with a Multiscan EX ELISA reader (Thermo Labsystems, Cheshire, WA, USA). In the assay, the solvent did not have any effect on the cell growth at the concentrations used for $\mathrm{IC}_{50}$ calculations. $\mathrm{IC}_{50}$ values and the SEM of triplicate experiments were calculated by using GraphPad Prism software version 5.00 for Windows with nonlinear regression curve fit (GraphPad Software, San Diego, CA, USA;www.graphpad.com).

\section{E. Fluorescence uptake assay}

The cell numbers of the L5178 MDR and L5178Y PAR cell lines were adjusted to $2 \times 10^{6}$ cells $/ \mathrm{mL}$, re-suspended in serum-free McCoy's 5A medium and distributed in $0.5 \mathrm{~mL}$ aliquots into Eppendorf centrifuge tubes. Steroid compounds were added at a final concentration of 2 $\mu \mathrm{g} / \mathrm{mL}$ and thioridazine and its enantiomers were added at a final concentration of 0.25 and 2.5 $\mu \mathrm{g} / \mathrm{mL}$, and the samples were incubated for $10 \mathrm{~min}$ at room temperature. Verapamil was applied as positive control at $10 \mu \mathrm{g} / \mathrm{mL}$. DMSO was added to the negative control tubes in the same volume as had been used for the tested compounds. No activity of DMSO was observed. Next, $10 \mu \mathrm{L}$ (5.2 $\mu \mathrm{M}$ final concentration) of the fluorochrome and ABCB1 substrate R123 was added to the samples and the cells were incubated for a further $20 \mathrm{~min}$ at $37^{\circ} \mathrm{C}$, washed twice and resuspended in $0.5 \mathrm{~mL}$ PBS for analysis. The fluorescence of the cell population was measured with a PartecCyFlow ${ }^{\circledR}$ flow cytometer (Partec, Münster, Germany). The percentage mean fluorescence intensity was calculated for the treated MDR cells as compared with the untreated cells. A fluorescence activity ratio (FAR) was calculated on the basis of the measured fluorescence values via the following equation [179]:

$$
\mathrm{FAR}=\frac{\text { MDR } \text { treated } / \text { MDR control }}{\text { parental treated } / \text { parental control }}
$$




\section{F. Apoptosis assay}

The capacity of the compounds to induce apoptosis was investigated by using the MDR mouse T-lymphoma cell line and the human PC3 prostate cancer cell line. The cell number was adjusted to $5 \times 10^{5}$ cells $/ \mathrm{mL}$ and the cells were distributed in $0.5 \mathrm{~mL}$ aliquots into 24 -well plates. The apoptosis inducer $12 \mathrm{H}$-benzo[ $\alpha$ ] phenothiazine (M627) was used as positive control at 25 $\mu \mathrm{g} / \mathrm{mL}$. Compounds were tested at $4 \mu \mathrm{g} / \mathrm{mL}$. Wells containing no M627 or steroidal compounds served as negative controls. The cells were incubated at $37{ }^{\circ} \mathrm{C}$ for $1 \mathrm{~h}$. At the end of the incubation period, the culture medium was removed, the cells were washed with PBS, and 0.5 $\mathrm{mL}$ of fresh culture medium was added to the cells. Samples were transferred to 24-well culture plates and further incubated overnight at $37^{\circ} \mathrm{C}$, under $5 \% \mathrm{CO}_{2}$. The apoptotic activities of the compounds were evaluated by using the Annexin- $\mathrm{V}$ fluorescein isothiocyanate (FITC) Apoptosis Detection Kit (Cat. No. PF 032 from Calbiochem, Merck KGaA, Darmstadt, Germany) according to the manufacturer's instructions. The fluorescence of the cell population was analyzed immediately, using a Partec CyFlow ${ }^{\circledR}$ flow cytometer (Partec, Münster, Germany). In case of PC3 prostate cancer cell line, the cells were seeded and incubated overnight at $37^{\circ} \mathrm{C}, 5 \% \mathrm{CO}_{2}$. After the treatment the same protocol was used as described above.

\section{G. Checkerboard combination assay}

A checkerboard microplate method was applied to study the effects of the drug interactions between $N$-hydroxyalkyl-2-aminophenothiazine derivatives and the chemotherapeutic drug doxorubicin on MDR colon adenocarcinoma cells overexpressing the ABCB1 transporter. The drug interactions between substituted steroid compounds and doxorubicin were also investigated on the PC3 prostate cancer cell line. The dilutions of doxorubicin were made in a horizontal direction in $100 \mu \mathrm{L}$, and the dilutions of the $\mathrm{N}$-hydroxyalkyl-2-aminophenothiazines or steroid compounds were made vertically in the microtiter plate in $50 \mu \mathrm{L}$. The cells were resuspended in culture medium and distributed into each well in $50 \mu \mathrm{L}$ containing $1 \times 10^{4}$ Colo 320 cells or $6 \times 10^{3} \mathrm{PC} 3$ prostate cancer cells. The plates were incubated for $72 \mathrm{~h}$ at $37{ }^{\circ} \mathrm{C}$ in a $\mathrm{CO}_{2}$ incubator. The cell growth rate was determined after MTT staining, as described above. The combination index $(\mathrm{CI})$ values at $50 \%$ growth inhibition $\left(\mathrm{ED}_{50}\right)$ were determined by using CompuSyn software to plot 4 or 5 data points for each ratio. CI values were calculated by means of the median-effect equation [180], where CI $<1, \mathrm{CI}=1$ and CI $>1$ represent synergism, an additive effect (or no interaction) and antagonism, respectively.

\section{H. Molecular docking}

The 2D structures of the chemical entities were drawn, and later energy-minimized into 3D structures by using Corina Online Demo [181]. All 3D structures were saved in PDB format ready to be docked. Molecular docking was conducted following a protocol previously reported by Zhao et al. [182]. 


\section{RESULTS}

\section{Antiproliferative effects of steroid and phenothiazine derivatives in different cancer models}

1. Antiproliferative effects of substituted steroidal compounds containing amino and amido groups on the PAR, MDR, LNCaP and PC3 cell lines

Twenty-three substituted steroid derivatives were synthesized, and their antiproliferative effects on the PAR, MDR, LNCaP and PC3 cell lines were studied. Evaluation of the antiproliferative activities of the compounds revealed that $\mathbf{8}$ and 10-14 were the most active against the parental mouse T-lymphoma cell line, with $\mathrm{IC}_{50}$ values of $<5 \mu \mathrm{g} / \mathrm{mL}$. With the exceptions of $\mathbf{9}$ and $\mathbf{1 3}$, all of the above-mentioned compounds and $\mathbf{2 2}$ were also active against the MDR cell line. As concerns the two different prostate cancer cell lines, the most effective compounds were $\mathbf{3}, \mathbf{1 2}$, 18, 19 and 23 against the LNCaP cells, and 12 against the PC3 cells. Thus, 12 was the only compound which exhibited strong activity against all four studied cell lines (Table II).

Table II. Antiproliferative effects of steroid derivatives on L5178 mouse T-lymphoma parental cell line (PAR) and its L5178Y human ABCB1-gene transfected subline (MDR),

$\mathrm{LNCaP}$ and PC3 prostate cancer cells

\begin{tabular}{|c|c|c|c|c|c|c|c|c|}
\hline \multirow{2}{*}{ CoMPOUND } & \multicolumn{2}{|c|}{ PAR } & \multicolumn{2}{c|}{ MDR } & \multicolumn{2}{c|}{ LNCaP } & \multicolumn{2}{c|}{ PC3 } \\
\cline { 2 - 9 } & $\begin{array}{c}\mathbf{I C}_{\mathbf{5 0}} \\
(\boldsymbol{\mu g} / \mathbf{m L})\end{array}$ & $\mathbf{S D}$ & $\begin{array}{c}\mathbf{I C}_{\mathbf{5 0}} \\
(\boldsymbol{\mu g} / \mathbf{m L})\end{array}$ & $\mathbf{S D}$ & $\begin{array}{c}\mathbf{I C}_{\mathbf{5 0}} \\
(\boldsymbol{\mu} \mathbf{g} \mathbf{m})\end{array}$ & $\mathbf{S D}$ & $\begin{array}{c}\mathbf{I C}_{\mathbf{5 0}} \\
(\boldsymbol{\mu g} / \mathbf{m L})\end{array}$ & SD \\
\hline $\mathbf{1}$ & 10.87 & 0.63 & 15.82 & 0.78 & 13.41 & 0.99 & 12.04 & 1.24 \\
\hline $\mathbf{2}$ & 9.80 & 0.24 & 19.13 & 0.1 & 13.09 & 1.41 & 12.49 & 1.09 \\
\hline $\mathbf{3}$ & $>12.5$ & - & 20.56 & 1.02 & 3.18 & 0.08 & 14.40 & 0.33 \\
\hline $\mathbf{4}$ & 11.38 & 0.70 & 15.12 & 2.74 & 9.53 & 1.65 & 13.26 & 1.55 \\
\hline $\mathbf{5}$ & $>12.5$ & - & 26.20 & 0.91 & 15.82 & 0.51 & $>25$ & - \\
\hline $\mathbf{6}$ & 9.97 & 0.04 & 12.33 & 0.57 & $>25$ & - & $>25$ & - \\
\hline $\mathbf{7}$ & 9.36 & 0.40 & 11.75 & 0.30 & $>25$ & - & $>25$ & - \\
\hline $\mathbf{8}$ & 2.89 & 0.04 & 4.81 & 0.83 & 13.74 & 0.31 & 13.31 & 1.78 \\
\hline $\mathbf{9}$ & 5.78 & 0.14 & 10.22 & 0.75 & 15.59 & 0.56 & 16.13 & 1.16 \\
\hline $\mathbf{1 0}$ & 1.34 & 0.05 & 1.34 & 0.13 & 7.77 & 1.21 & 13.93 & 0.50 \\
\hline $\mathbf{1 1}$ & 3.91 & 0.04 & 5.08 & 0.83 & 11.72 & 2.16 & $>12.5$ & - \\
\hline $\mathbf{1 2}$ & 0.99 & 0.01 & 1.12 & 0.16 & 4.68 & 0.41 & 5.21 & 0.66 \\
\hline $\mathbf{1 3}$ & 1.47 & 0.23 & 8.83 & 2.84 & $>25$ & - & $>25$ & - \\
\hline $\mathbf{1 4}$ & 4.19 & 0.04 & 5.57 & 0.47 & 16.61 & 1.93 & 13.22 & 0.55 \\
\hline $\mathbf{1 5}$ & $>12.5$ & - & 16.32 & 1.52 & $>25$ & - & $>25$ & - \\
\hline $\mathbf{1 6}$ & 11.63 & 0.27 & 14.67 & 1.38 & 9.57 & 2.22 & 16.86 & 2.68 \\
\hline $\mathbf{1 7}$ & 10.66 & 0.48 & 11.05 & 11.05 & 8.93 & 4.85 & 18.52 & 0.47 \\
\hline $\mathbf{1 8}$ & $>12.5$ & - & $>25$ & - & 3.62 & 0.01 & 15.29 & 2.01 \\
\hline $\mathbf{1 9}$ & $>12.5$ & - & $>25$ & - & 7.48 & 0.03 & 13.22 & 7.06 \\
\hline $\mathbf{2 0}$ & $>12.5$ & - & $>25$ & - & 16.27 & 6.69 & $>25$ & - \\
\hline $\mathbf{2 1}$ & $>12.5$ & - & $>25$ & - & $>25$ & - & $>25$ & - \\
\hline $\mathbf{2 2}$ & 11.71 & 0.16 & 6.80 & 1.86 & 10.15 & 2.57 & 14.54 & 0.61 \\
\hline $\mathbf{2 3}$ & $>12.5$ & - & $>25$ & - & 9.23 & 1.60 & 15,00 & 0.70 \\
\hline
\end{tabular}




\section{Antiproliferative effects of phenothiazine derivatives on PAR, MDR, LNCaP, and PC3 cell lines}

\section{a) $\mathrm{N}$-hydroxyalkyl-2-aminophenothiazine derivatives}

The $N$-hydroxyalkyl-2-aminophenothiazine derivatives displayed more potent cytotoxic effects on the resistant colon adenocarcinoma cell than on the sensitive cell line Colo 205. The $\mathrm{IC}_{50}$ values of the derivatives on the sensitive cell line Colo 205 can be divided into four groups: those with an $\mathrm{IC}_{50}$ of $>100 \mu \mathrm{M}$ : 1i, 3f, 3g, 3h and 3i; those with an $\mathrm{IC}_{50}$ in the interval 20-55 $\mu \mathrm{M}$ : 1a, 1b, 1d, 1f, 1g, 1l, 1n, 3a, 3b, 3c and 3e; those with an $\mathrm{IC}_{50}$ in the interval 10-19 $\mu \mathrm{M}$ : 1c, 1j, 1m, 2, 3d and 3j; and those with an $\mathrm{IC}_{50}$ in the interval 5-9 $\mu \mathrm{M}$ : 1e, $1 \mathbf{h}$ and $\mathbf{1 k}$. The compounds were more selective for the MDR Colo 320 cells, as shown by their lower $\mathrm{IC}_{50}$ values. In this case, the compounds can be divided into three categories: those with an $\mathrm{IC}_{50}$ in the interval 10-40 $\mu \mathrm{M}$ : 1a, 1b, 1d, 1e, 1f, 1g, 1i, $\mathbf{1 l}$ and 3a; those with an $\mathrm{IC}_{50}$ in the interval 3-10 $\mu \mathrm{M}$ : 1c, 1h, 1j, 1m, 1n, 2, 3c, 3d, 3e, 3f, 3i and 3j; and those with an $\mathrm{IC}_{50}$ of $<3 \mu \mathrm{M}$ : 1k, 1o, 3b, $\mathbf{3 g}$ and $\mathbf{3 h}$ (Table III).

Table III. Antiproliferative activities of $N$-hydroxyalkyl-2-aminophenothiazines on MDR Colo 320 colon adenocarcinoma cells

\begin{tabular}{|c|c|c|c|c|c|}
\hline \multicolumn{6}{|c|}{ ANTIPROLIFERATIVE EFFECT } \\
\hline DERIVATIVES & $\begin{array}{l}\mathrm{IC}_{50} \\
(\mu \mathrm{M})\end{array}$ & SD & DERIVATIVES & $\begin{array}{l}\mathrm{IC}_{50} \\
(\mu \mathrm{M})\end{array}$ & SD \\
\hline $1 \mathbf{a}$ & 14.83 & 1.15 & 10 & 2.90 & 0.62 \\
\hline $1 \mathrm{~b}$ & 12.85 & 1.45 & 2 & 3.88 & 0.14 \\
\hline $1 \mathrm{c}$ & 7.29 & 0.57 & $3 \mathbf{a}$ & 16.91 & 1.79 \\
\hline 1d & 38.85 & 1.42 & $3 \mathbf{b}$ & 2.71 & 0.09 \\
\hline $1 \mathrm{e}$ & 18.64 & 0.40 & $3 c$ & 3.02 & 0.11 \\
\hline 1f & 21.58 & 1.82 & 3d & 3.09 & 0.23 \\
\hline $1 \mathrm{~g}$ & 25.16 & 0.53 & $3 \mathbf{e}$ & 3.07 & 0.09 \\
\hline $1 \mathrm{~h}$ & 3.325 & 0.19 & 3f & 4.02 & 0.23 \\
\hline $1 \mathrm{i}$ & 41.49 & 1.46 & $3 g$ & 2.83 & 0.04 \\
\hline $1 \mathbf{j}$ & 7.50 & 0.95 & $3 \mathbf{h}$ & 2.89 & 0.17 \\
\hline $1 \mathrm{k}$ & 2.83 & 0.24 & $3 \mathbf{i}$ & 4.67 & 0.13 \\
\hline 11 & 11.24 & 2.60 & $\mathbf{3 j}$ & 3.59 & 0.33 \\
\hline $1 \mathrm{~m}$ & 3.60 & 0.16 & DMSO (v/v\%) & 2.19 & 0.06 \\
\hline $1 \mathrm{n}$ & 3.43 & 0.25 & - & - & - \\
\hline
\end{tabular}

\section{b) Racemic thioridazine and its (+) and (-) enantiomers}

The antiproliferative effects of the racemate and (+) and (-) enantiomers of TZ on MDR mouse Tlymphoma cells are summarized in Figure 3. No significant differences were found between the three compounds as concerns the antiproliferative activity against the MDR mouse T-lymphoma cell line. 

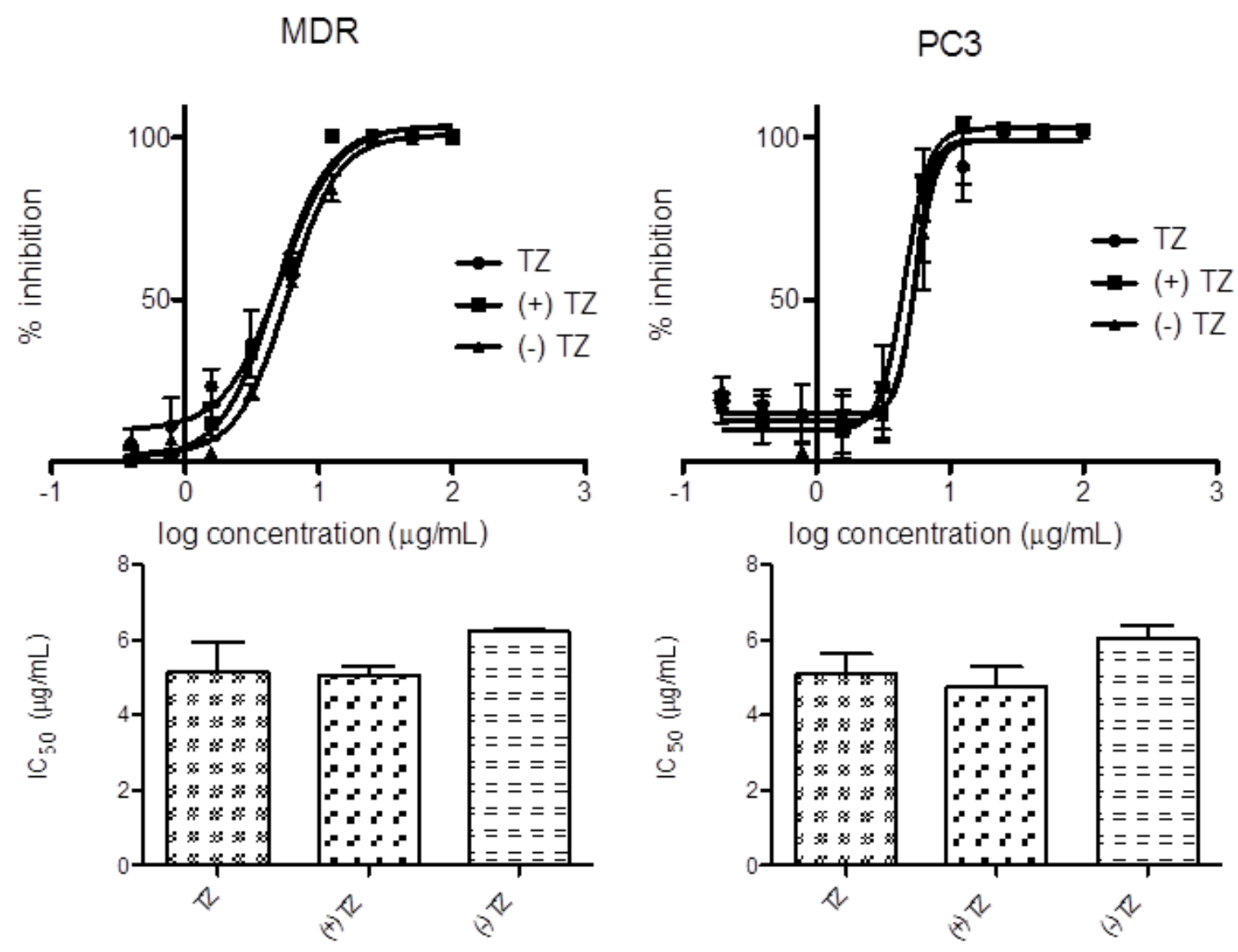

\begin{tabular}{|l|c|c|c|c|}
\hline \multirow{2}{*}{ CoMPounds } & \multicolumn{4}{|c|}{ Mean IC $\mathbf{5 0}_{\mathbf{0}}(\boldsymbol{\mu \mathbf { g } / \mathbf { m L } )}$} \\
\cline { 2 - 5 } & MDR & SEM & PC3 & SEM \\
\hline TZ racemate & 5.14 & 0.83 & 5.09 & 0.56 \\
\hline (+) enantiomer & 5.06 & 0.24 & 4.74 & 0.54 \\
\hline (-) enantiomer & 6.23 & 0.07 & 6.05 & 0.34 \\
\hline
\end{tabular}

Figure 3. Antiproliferative effects of racemic TZ and its (+) and (-) enantiomers on mouse

$\mathrm{T}$-lymphoma and prostate cancer cells. The mean $\mathrm{IC}_{50}$ was calculated on the basis of the results of three independent experiments. SEM: Standard error of the mean.

\section{Cytotoxic effects of steroid derivatives on PAR and MDR mouse T-lymphoma cells}

It can be concluded that the steroid derivatives possess slight cytotoxic effects, although there was no significant difference between the parental and the MDR mouse T-lymphoma cells. The most active derivatives were $\mathbf{4 ,} 9$ and 12 (Table IV). 
Table IV. Cytotoxic effects of steroid derivatives on PAR and MDR mouse T-lymphoma cells

\begin{tabular}{|c|c|c|c|c|}
\hline \multirow[b]{2}{*}{ COMPOUNDS } & \multicolumn{2}{|c|}{ PAR } & \multicolumn{2}{|c|}{ MDR } \\
\hline & $\begin{array}{c}\mathrm{IC}_{50} \\
(\mu \mathrm{g} / \mathrm{mL})\end{array}$ & SEM & $\begin{array}{c}\mathrm{IC}_{50} \\
(\mu \mathrm{g} / \mathrm{mL})\end{array}$ & SEM \\
\hline 1 & 8.13 & 0.63 & 17.44 & 0.01 \\
\hline 2 & 13.2 & 0.41 & 16.46 & 1.00 \\
\hline 3 & 9.51 & 1.16 & 17.33 & 0.36 \\
\hline 4 & 6.58 & 0.30 & 9.72 & 1.68 \\
\hline 5 & 20.7 & 0.34 & $>25$ & - \\
\hline 6 & 20.87 & 4.10 & $>25$ & - \\
\hline 7 & 22.78 & 1.40 & $>25$ & - \\
\hline 8 & 13.82 & 0.07 & 13.27 & 0.92 \\
\hline 9 & 5.7 & 0.29 & 7.06 & 0.23 \\
\hline 10 & 8.41 & 0.44 & 7.40 & 0.42 \\
\hline 11 & 11.77 & 0.05 & 10.1 & 0.39 \\
\hline 12 & 3.44 & 0.01 & 2.71 & 0.13 \\
\hline 13 & $>50$ & - & $>25$ & - \\
\hline 14 & 7.85 & 0.26 & 12 & 0.69 \\
\hline 15 & 20.12 & 0.88 & $>25$ & - \\
\hline 16 & 11.83 & 0.01 & 14.58 & 0.33 \\
\hline 17 & 13.7 & 0.56 & $>25$ & - \\
\hline 18 & 14.59 & 0.18 & 20.23 & 0.91 \\
\hline 19 & 15.88 & 0.36 & 21.81 & 1.06 \\
\hline 20 & 26.85 & 0.82 & $>25$ & - \\
\hline 21 & $>50$ & - & $>25$ & - \\
\hline 22 & 15.91 & 0.08 & $>25$ & - \\
\hline 23 & $>50$ & - & $>25$ & - \\
\hline
\end{tabular}

\section{Multidrug resistance reversal effect of different compounds on MDR cells}

\section{Substituted steroids}

Twenty-three modified steroid derivatives were examined on MDR cells in R123 excluding shortterm experiments at subinhibitory concentrations for $30 \mathrm{~min}$. In this experiment, $2 \times 10^{6}$ cells were exposed to $2 \mu \mathrm{g} / \mathrm{mL}$ final concentrations for $10 \mathrm{~min}$ before indicator R123 was added to the cells. The aminosteroid compounds acylated with BOC-amino acids (1-5 and 9) and even the simple $N$-acetyl derivatives $(13,16,18$ and 19) displayed pronounced activity in the reversal of the MDR of the MDR mouse T-lymphoma cell line, with FAR values between 29 and 77. Steroids containing free amino groups or aminehydrochloride substituents demonstrated weaker or no activity on MDR reversal as measured by the accumulation of R123. Interestingly, $\mathbf{1 2}$ exhibited only mild inhibition at the concentration used. As concerns the activities expressed in $\mu \mathrm{M}$, the most active compound was $\mathbf{1 8}$, with an FAR of 77.41 at $4.4 \mu \mathrm{M} . \mathbf{1 6}, \mathbf{1 3}, \mathbf{1}, \mathbf{1 9}$ and $\mathbf{3}$ were also highly active (Table V). 
Table $\boldsymbol{V}$. A comparison of the effects of aminosteroid derivatives on the activity of the ABCB1 transporter in mouse T-lymphoma cells by flow cytometry. Compounds were tested at $2 \mu \mathrm{g} / \mathrm{mL}$. Verapamil was used as positive control at $10 \mu \mathrm{g} / \mathrm{mL}$.

\begin{tabular}{|c|c|c|c|}
\hline COMPOUND & FAR & COMPOUND & FAR \\
\hline VERAPAMIL & 17.21 & $\mathbf{1 3}$ & 58.79 \\
\hline $\mathbf{1}$ & 54.28 & $\mathbf{1 4}$ & 2.20 \\
\hline $\mathbf{2}$ & 37.64 & $\mathbf{1 5}$ & 1.76 \\
\hline $\mathbf{3}$ & 59.28 & $\mathbf{1 6}$ & 75.48 \\
\hline $\mathbf{4}$ & 37.92 & $\mathbf{1 7}$ & 16.69 \\
\hline $\mathbf{5}$ & 29.07 & $\mathbf{1 8}$ & 77.41 \\
\hline $\mathbf{6}$ & 9.21 & $\mathbf{1 9}$ & 52.90 \\
\hline $\mathbf{7}$ & 10.21 & $\mathbf{2 0}$ & 45.82 \\
\hline $\mathbf{8}$ & 1.47 & $\mathbf{2 1}$ & 1.07 \\
\hline $\mathbf{9}$ & 39.14 & $\mathbf{2 2}$ & 10.43 \\
\hline $\mathbf{1 0}$ & 1.19 & $\mathbf{2 3}$ & 12.26 \\
\hline $\mathbf{1 1}$ & 2.77 & DMSO & 0.78 \\
\hline $\mathbf{1 2}$ & 7.41 & - & - \\
\hline
\end{tabular}

FAR: Fluorescence activity ratio, calculated via the equation given in the Materials and Methods; DMSO: dimethyl sulfoxide.

\section{Racemic thioridazine and its (+) and (-) enantiomers}

The effects of the racemic and the (+) and (-) enantiomers of thioridazine on the retention of R123 in the MDR mouse lymphoma cell line were studied at 0.25 and $2.5 \mu \mathrm{g} / \mathrm{mL}$ (Table VI). At $0.25 \mu \mathrm{g} / \mathrm{mL}, \mathrm{TZ}$ and its enantiomers moderately inhibited the ABCB 1 expressed by the MDR mouse T-cell lymphoma cell line, while at $2.5 \mu \mathrm{g} / \mathrm{mL}$ the inhibition was stronger, without apparent stereospecificity, which appears to be a promising finding.

Table VI. Reversal of the multidrug resistance of MDR mouse T-lymphoma cells in the presence of low doses of TZ.

\begin{tabular}{|l|c|c|c|c|c|}
\hline & $\boldsymbol{\mu g} / \mathbf{m L}$ & FSC & SSC & FL1 & FAR \\
\hline L5178Y ( PAR) & - & 1573 & 674 & 52.4 & - \\
\hline $\begin{array}{l}\text { L5178Y (ABCB1 expressing, } \\
\text { MDR) }\end{array}$ & - & 1601 & 629 & 0.545 & - \\
\hline Verapamil & 10 & 1587 & 628 & 14.9 & 27.34 \\
\hline \multirow{2}{*}{ TZ racemate } & 0.25 & 1601 & 625 & 2.65 & 4.86 \\
\hline \multirow{2}{*}{$(+)$ enantiomer } & 2.50 & 1609 & 618 & 34.7 & 63.66 \\
\hline \multirow{2}{*}{ (-) enantiomer } & 0.25 & 1590 & 626 & 1.73 & 3.17 \\
\cline { 2 - 6 } & 2.50 & 1614 & 626 & 33.5 & 61.46 \\
\cline { 2 - 6 } & 0.25 & 1602 & 636 & 1.35 & 2.47 \\
\hline
\end{tabular}




\section{Combination of steroid and $N$-hydroxyalkyl-2-aminophenothiazine derivatives with doxorubicin in different cancer models}

\section{The effects of substituted steroid compounds combined with doxorubicin on PC3 cells}

The effects of the substituted steroid compounds on the activity of doxorubicin were observed to vary from ineffective to strong synergy. Five compounds gave rise to strong synergy with doxorubicin: 4, 9, 10, 14 and 22. Moderate synergy was observed with 1, 2, 8, 12, 16, 17, 19 and 23, while 3 and 18 were ineffective. The $\mathrm{IC}_{50}$ values of $5-7,11,13,15,20$ and 21 could not be calculated, and the interactions of these compounds with doxorubicin could therefore not be determined (Table VII).

Table VII. Types of interaction between doxorubicin and 16 amidosteroid derivatives against the PC3 prostate cancer cell line

\begin{tabular}{|c|r|c|c|}
\hline COMPOUND & Ratio $^{\mathbf{a}}$ & CI $^{\mathbf{b}}$ & INTERACTION \\
\hline $\mathbf{1}$ & $5: 1$ & 0.44 & Synergism \\
\hline $\mathbf{2}$ & $5: 1$ & 0.47 & Synergism \\
\hline $\mathbf{3}$ & $10: 1$ & 0.91 & No interaction \\
\hline $\mathbf{4}$ & $5: 1$ & 0.28 & Strong synergism \\
\hline $\mathbf{8}$ & $10: 1$ & 0.40 & Synergism \\
\hline $\mathbf{9}$ & $10: 1$ & 0.17 & Strong synergism \\
\hline $\mathbf{1 0}$ & $10: 1$ & 0.26 & Strong synergism \\
\hline $\mathbf{1 2}$ & $5: 1$ & 0.55 & Synergism \\
\hline $\mathbf{1 4}$ & $10: 1$ & 0.29 & Strong synergism \\
\hline $\mathbf{1 6}$ & $10: 1$ & 0.53 & Synergism \\
\hline $\mathbf{1 7}$ & $10: 1$ & 0.38 & Synergism \\
\hline $\mathbf{1 8}$ & $10: 1$ & 0.96 & No interaction \\
\hline $\mathbf{1 9}$ & $20: 1$ & 0.61 & Synergism \\
\hline $\mathbf{2 2}$ & $20: 1$ & 0.27 & Strong synergism \\
\hline $\mathbf{2 3}$ & $20: 1$ & 0.30 & Synergism \\
\hline
\end{tabular}

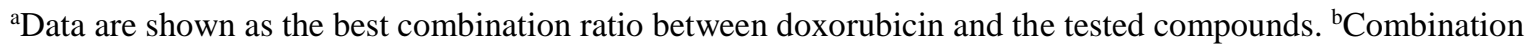
index $(\mathrm{CI})$ values at $50 \%$ growth inhibition $\left(\mathrm{ED}_{50}\right)$ were determined by using CompuSyn software to plot 4 or 5 data points for each ratio. CI values were calculated by means of the median-effect equation, where $\mathrm{CI}<1, \mathrm{CI}=1$ and CI >1 represent synergism, an additive effect (i.e. no interaction) and antagonism, respectively [180].

\section{The effects of $\mathrm{N}$-hydroxyalkyl-2-aminophenothiazine derivatives with doxorubicin}

With regard to the ABCB1-modulating activities of the lead $N$-hydroxyalkyl-2-aminophenothiazine compounds, six derivatives were selected for combination studies with doxorubicin. As shown in Table VIII, all of them exhibited synergistic activity with doxorubicin at an $\mathrm{N}$-hydroxyalkyl-2aminophenothiazine derivative:doxorubicin ratio of 12:1. It can be concluded that the lead compound of the $N$-hydroxyalkyl-2-aminophenothiazine series was $\mathbf{3 j}$, which showed synergism with the anticancer drug doxorubicin on MDR colon adenocarcinoma cells. 
Table VIII. Types of interaction between $N$-hydroxyalkyl-2-aminophenothiazine derivatives and doxorubicin in MDR Colo 320 colon adenocarcinoma cells. CI: combination index

\begin{tabular}{|c|c|c|c|}
\hline DERIVATIVE & Ratio & CI & INTERACTION \\
\hline $\mathbf{1 c}$ & $12: 1$ & 0.31 & Synergism \\
\hline $\mathbf{3 d}$ & $12: 1$ & 0.14 & Strong synergism \\
\hline $\mathbf{3 g}$ & $12: 1$ & 0.17 & Strong synergism \\
\hline $\mathbf{3 h}$ & $12: 1$ & 0.11 & Strong synergism \\
\hline $\mathbf{3 i}$ & $12: 1$ & 0.10 & Strong synergism \\
\hline $\mathbf{3 j}$ & $12: 1$ & 0.29 & Strong synergism \\
\hline
\end{tabular}

\section{Evaluation of selected compounds as possible apoptosis inducers on the PC3 prostate cancer cell line}

\section{Apoptosis-inducing effects of substituted steroid derivatives containing amino and amido groups on the PC3 cell line}

The apoptosis-inducing effects of the substituted steroid compounds on the PC3 cell line were measured at the nontoxic concentration of $4 \mu \mathrm{g} / \mathrm{mL}$ (no data are shown). These compounds proved to exert no relevant apoptosis-inducing activity: the proportion of early apoptosis was $1-6 \%$, those of late apoptosis and necrosis were $1-5 \%$, and that of cell death was around $1 \%$. No significant difference was seen when these data were compared with those on the untreated control.

\section{Apoptosis-inducing effects of racemic thioridazine and its enantiomers on human ABCB1-carrying mouse T-lymphoma and PC3 prostate cancer cell lines}

The apoptosis induction assays were carried out at 2.5 and $5 \mu \mathrm{g} / \mathrm{mL}$ racemic thioridazine and its enantiomers in MDR mouse T-lymphoma cells. Racemic TZ and the enantiomers displayed similar apoptosis-inducing activities, suggesting that stereoselectivity does not play a role in the induction of apoptosis (Table IX). Both racemic TZ and the enantiomers induced early apoptosis in PC3 cells, but there was no significant difference between them (Table X). Our results clearly demonstrated that racemic thioridazine and its enantiomers have essentially the same activity against cancer cell lines with respect to the inhibition of replication and the induction of apoptosis. 
Table IX. Apoptosis induction of ABCB1-expressing MDR cells by $\mathrm{TZ}$ and its enantiomers after a $1 \mathrm{~h}$ incubation

\begin{tabular}{|c|c|c|c|c|}
\hline \multirow{2}{*}{ TREATMENT } & \multicolumn{4}{|c|}{ GATED EVENS \% } \\
\cline { 2 - 5 } & $\begin{array}{c}\text { CONCENTRATION } \\
(\mu \mathrm{g} / \mathrm{mL})\end{array}$ & $\begin{array}{c}\text { EARLY } \\
\text { APOPTOSIS }\end{array}$ & $\begin{array}{c}\text { LATE APOPTOSIS } \\
\text { AND NECROSIS }\end{array}$ & CELL DEATH \\
\hline Untreated control & & 5.74 & 2.8 & 0.164 \\
\hline M627 & 50 & 61.6 & 34.3 & 0.107 \\
\hline \multirow{2}{*}{ TZ racemate } & 2.5 & 19.9 & 1.15 & 0.18 \\
\cline { 2 - 5 } & 5 & 48.1 & 2.52 & 0.2 \\
\hline \multirow{2}{*}{$(+)$ enantiomer } & 2.5 & 19.4 & 1.8 & 0.378 \\
\hline \multirow{2}{*}{$(-)$ enantiomer } & 5 & 40 & 1.84 & 0.164 \\
\cline { 2 - 5 } & 2.5 & 9.6 & 3.81 & 0.458 \\
\hline DMSO & 5 & 54.3 & 2.17 & 0.128 \\
\hline
\end{tabular}

Untreated control: FITC-labeled annexin V and PI.

Table X. Apoptosis induction of PC3 cells by TZ and its enantiomers after a $1 \mathrm{~h}$ incubation

\begin{tabular}{|c|c|c|c|c|}
\hline \multirow{2}{*}{ TREATMENT } & \multicolumn{4}{|c|}{ GATED EVETS \% } \\
\cline { 2 - 5 } & $\begin{array}{c}\text { CONCENTRATION } \\
(\mu \mathrm{g} / \mathrm{mL})\end{array}$ & $\begin{array}{c}\text { EARLY } \\
\text { APOPTOSIS }\end{array}$ & $\begin{array}{c}\text { LATE APOPTOSIS } \\
\text { AND NECROSIS }\end{array}$ & CELL DEATH \\
\hline Untreated control & & 0.776 & 2.03 & 5.49 \\
\hline DMSO & $5 \%$ & 1.1 & 1.92 & 3.8 \\
\hline M627 & 25 & 42 & 4.75 & 2.92 \\
\hline \multirow{2}{*}{ Tz racemate } & 20 & 1.72 & 3.01 & 3.4 \\
\cline { 2 - 5 } & 40 & 7.98 & 3.31 & 2.35 \\
\hline \multirow{2}{*}{$(+)$ Enantiomer } & 20 & 1.75 & 4.44 & 1.44 \\
\hline \multirow{2}{*}{$(-)$ Enantiomer } & 40 & 3.11 & 3.48 & 3.15 \\
\cline { 2 - 5 }
\end{tabular}

Untreated control: FITC-labeled annexin V and PI.

\section{Molecular docking of substituted steroid derivatives containing amino and amido groups to the ABCB1 transport protein}

Molecular docking is an effective computational technique which provides an estimate of the binding energy of a compound to the target protein. A scoring system is used to detect the ideal docking configuration. The amino acids involved in hydrophobic and hydrogen-bonding interactions are also predicted by the algorithm. Our molecular docking results suggested that the tested compounds inhibit ABCB1 protein (P-gp) activity through binding to the drugbinding pocket, which is the same binding site as that for verapamil. We carried out in silico investigations of the interaction of the panel of steroid compounds with P-gp, using verapamil as a positive control. All 23 compounds exhibited binding energies lower than that of verapamil. The binding energies ranged from -6.43 to $-9.88 \mathrm{kcal} / \mathrm{mol}$. The predicted inhibition constants ranged from 0.1 to $10.1 \mu \mathrm{M}$. (Table XI). Most of the compounds with high activity and 
verapamil share one or more amino acids in their binding sites. It appears that there is a significant correlation between the binding energies of the compounds and their FARs.

Table XI. Results of molecular docking of steroidal compounds to the ABCB1 transmembrane protein

\begin{tabular}{|c|c|c|c|c|c|}
\hline \multirow[t]{2}{*}{ COMPOUND } & \multicolumn{2}{|c|}{$\begin{array}{c}\text { BINDING ENERGY } \\
(\mathrm{KCAL} / \mathrm{MOL})\end{array}$} & \multicolumn{2}{|c|}{ PKI $(\mu \mathrm{M})$} & \multirow{2}{*}{$\begin{array}{l}\text { HYDROGEN BOND- } \\
\text { FORMING AAS }\end{array}$} \\
\hline & MEAN & SEM & MEAN & SEM & \\
\hline VERAPAMIL & -5.64 & 0.41 & 0.9 & 0.2 & Val 862 \\
\hline 1 & -7.94 & 0.08 & 1.5 & 0.2 & Gln 946 \\
\hline 2 & -7.71 & 0.19 & 2.4 & 0.7 & - \\
\hline 3 & -8.34 & 0.26 & 0.8 & 0.3 & - \\
\hline 4 & -7.66 & 0.02 & 2.4 & 0.1 & Gln 347 \\
\hline 5 & -8.39 & 0.06 & 0.7 & 0.1 & Tyr 953 \\
\hline 6 & -6.97 & 0.08 & 7.8 & 1.0 & - \\
\hline 7 & -6.44 & 0.01 & 18.9 & 0.2 & Asp 188; Gln 195 \\
\hline 8 & -6.55 & 0.20 & 9.7 & 0.1 & - \\
\hline 9 & -8.49 & 0.06 & 0.6 & 0.1 & Gln 347 \\
\hline 10 & -6.81 & 0.02 & 10.1 & 0.2 & Asp 188 \\
\hline 11 & -7.30 & 0.06 & 4.5 & 0.4 & Thr 945 \\
\hline 12 & -7.67 & 0.06 & 2.4 & 0.2 & Asp 188; Gln 195 \\
\hline 13 & -7.31 & 0.09 & 4.4 & 0.7 & - \\
\hline 14 & -7.80 & 0.01 & 1.9 & 0.0 & - \\
\hline 15 & -7.20 & 0.00 & 5.5 & 0.3 & Asp 188 \\
\hline 16 & -8.54 & 0.10 & 0.6 & 0.1 & - \\
\hline 17 & -8.30 & 0.18 & 0.9 & 0.2 & - \\
\hline 18 & -9.04 & 0.01 & 0.2 & 0.0 & Asp 886; Lys 934 \\
\hline 19 & -9.27 & 0.03 & 0.2 & 0.0 & - \\
\hline 20 & -9.88 & 0.07 & 0.1 & 0.0 & - \\
\hline 21 & -8.23 & 0.12 & 1.1 & 0.0 & - \\
\hline 22 & -9.84 & 0.02 & 0.1 & 0.0 & - \\
\hline 23 & -6.43 & 0.10 & 19.5 & 3.5 & - \\
\hline
\end{tabular}

Lowest binding energy, predicted inhibition constant (Pki) and amino acids (AA) involved in hydrogen-bonding for each compound are shown. Each docking experiment was repeated three times (data are presented as the mean and SEM). 


\section{DISCUSSION}

Cancer, the second worldwide cause of death after cardiovascular diseases [183], is characterized by uncontrolled cell proliferation and the absence of cell death, which leads to the generation of an abnormal cell mass or tumor. Due to new vascularization, this primary tumor grows and acquires metastatic potential and spreads to other body parts, which causes metastasis and finally results in death. Cancer is caused by damage or mutations in the genetic material of the cells, due to environmental or inherited factors. While surgery and radiotherapy are the primary modes of treatment for local and nonmetastatic cancers, anticancer drugs are the current choice in the therapy of metastatic cancers. Chemotherapy also affects normal cells, generating the characteristic sideeffects of chemotherapy. The indiscriminate destruction of normal cells, the toxicity of conventional chemotherapeutic drugs, and the development of MDR support the need for new, effective targeted therapies based on the changes in the molecular biology of the tumor cells $[183,184,185]$.

The main aim of our study was to evaluate the effects of phenothiazine derivatives and substituted steroid compounds in different cancer models, such as mouse T-lymphoma cell lines, colon adenocarcinoma cancer cell lines, and prostate cancer cell lines. The MDR transporters are one of the main causes of cancer treatment failures [169]. Modulation of efflux pump-related mechanisms, in order to increase the activity of existing chemotherapeutics to which cancer becomes resistant, is one of the possible ways to overcome resistance.

In our investigation, modified steroid derivatives without hormonal activity were chosen to achieve this effect. The results revealed that $8,10-12,14$ and 22 exerted effective antiproliferative activity against MDR mouse T-lymphoma cells expressing ABCB1. These compounds are aminoacylamide salts based on three different steroid skeletons (androstane, androstene and pregnadienes). 22 is an estrone ether derivative and has a bidentate $\alpha$-hydroxymethylene-ketone arrangement on the D-ring, allowing the possibility of a 1,4-hydrogen donor-acceptor connection. On the other hand, 3, 12, 18, 19 and 23 proved to be effective in the antiproliferative assays against the LNCaP prostate cell line. In the MDR reversal studies, a majority of the investigated compounds were effective: 1-5, 9, 13 and 16-20 (Table V). In contrast, 6, 8, 10-12, 14, 15 and 21 had only weak effects. These latter molecules are either amine hydrochlorides, or possess special structures; 14, 15 and 21 are estrone-ether derivatives. Aminosteroids with basic primary amino groups had practically no effect. The compounds with marked activity contain four different steroid skeletons, four different aminoacyl moieties (glycyl, alanyl, phenylalanyl and prolyl) and, in the case of the simpler molecules, three different alkyl (propyl, benzyl and acethoxyethyl) moieties. Their only common structural element is the amide, derived from an $\alpha$-amino acid or acetic acid. In 18 and 19, a double bond is present in rings $\mathrm{A}$ and $\mathrm{B}$ in addition to there being no $\mathrm{H}$ atom on $\mathrm{C}-5$. This $\mathrm{H}$ atom either induces or is responsible for conformational changes in the four condensed rings with a chair-like structure. In the case of $\mathbf{1 3}$, the 
hydrophobic steroid containing the acyl-amide can help binding to the $\beta$-turn of the ABCB1 protein. We presume that the biologically active $N$-protected BOC compounds bind to particular $\beta$-turns of the ABCB1 transporter. There are possibly preferred amino acids in the $\beta$-turns that may have a key role in maintaining the functionally active conformations of the ABCB1 transporter localized in the cell membrane. Molecular docking is an effective computational technique which estimates the binding energy of a compound to the target protein. A scoring system is used to detect the ideal docking configuration. The amino acids involved in hydrophobic and hydrogen-bond interactions are also predicted by the algorithm. Our molecular docking results suggested that the tested compounds inhibit $\mathrm{ABCB} 1$ activity through binding to the drug-binding pocket of the transporter, which is the same binding site as for verapamil. Most of the compounds with high activity and verapamil share one or more amino acids in their binding sites. It appears that there is a significant correlation between the binding energies of the compounds and their FARs. It can be suggested that molecular docking might be used as a tool for prediction of the activity of steroidal compounds as inhibitors of ABCB1. A large number of the compounds were able to enhance the activity of doxorubicin against the PC3 cell line in combination experiments. On the basis of our results, 9 could be a lead compound for further investigations relating to combined chemotherapy, while $\mathbf{1 2}$ might be a promising candidate as an effective antiproliferative chemotherapeutic agent.

Phenothiazines have been proven to be a special group of compounds with extraordinary anticancer [186, 187, 188] and antibacterial activities [189]. Besides their various biochemical effects [190], $N$ hydroxyalkyl-2-aminophenothiazines may be promising candidates for combined anticancer chemotherapy [64]. The investigated $N$-hydroxyalkyl-2-aminophenothiazines exert promising antiproliferative effects on MDR colonic adenocarcinoma cells. The nature of the substituents can strongly influence the anticancer activity of the derivatives. From our understanding of the relationship between structural diversity and activity, we concluded that the compounds substituted with secondary amines (morpholine, diethylamine or $N$-methylpiperazine) at position 2 in the phenothiazine ring $\left(\mathbf{3 c}, \mathbf{3 d}\right.$ and $\mathbf{3 f}$ ) were the most selective candidates. Further, the $\mathrm{IC}_{50}$ data revealed that the oxidized form of the sulfur atom (sulfoxide or sulfone) led to marked selectivity ( $\mathbf{3 h}, \mathbf{3 i}$ and 3j). The compounds containing a primary amine or acid amide at position 2 in the ring, such as 1c, $\mathbf{1 h}, \mathbf{1 j}, \mathbf{1 m}$ and $\mathbf{1 n}$, displayed lower activities as compared with those of the aforementioned molecules. It can be assumed that the modulation of similar structural details (secondary amines at position 2, a 2-hydroxy group in the alkyl chain, sulfoxide or sulfone) of the chosen lead compounds $(\mathbf{1 c}, \mathbf{3 d}, \mathbf{3 g}, \mathbf{3 h}, \mathbf{3 i}$ and $\mathbf{3 j}$ ) is responsible for the synergism with doxorubicin. The antiproliferative activity clearly demonstrated that the oxidation of the sulfur atom in $\mathbf{1 h}$ resulted in the lead molecule 3j. It can be concluded that this structural modification increased the biological activity. To understand this effect, further binding assays could furnish more biophysical and biochemical information about the anticancer activity of these compounds. 
The importance of stereochemistry in drug action is gaining ever-greater attention in medical practice. Many of the drugs currently used in psychiatric practice are mixtures of enantiomers. For some therapeutics, single-enantiomer formulations can provide greater selectivity for their biological targets, improved therapeutic indices, and/or better pharmacokinetics than a mixture of enantiomers. When both a single enantiomer and a racemic formulation of a drug are available, the information from experimental trials should be used to decide which formulation is most appropriate [191]. In our study, the potential advantages of using single enantiomers of a chiral drug were investigated. The isolation and stability of enantiomers is dependent on the local milieu [192]. The presented equilibrium between the (+) and (-) isomers influences the binding affinities of the enantiomers to different ligands or receptors. "Do the racemate TZ and its enantiomers express different activities against cancer cell lines?" This question was based upon observations published by others which suggested that "the (-)-TZ enantiomer had slightly more catalepsy (neuroleptic)" [193]. Nevertheless, as a variety of pharmacological studies reported by Svendsen et al. [193] indicated significantly greater binding of the (-)-TZ enantiomer to the D1 receptor in the rodent brain, we, like others [194, 195], studied the activities of the racemate TZ (which consists of equal concentrations of the (+) and (-) enantiomers) and each enantiomer against cancer cell lines. Our results clearly demonstrated that the racemate $\mathrm{TZ}$ and its enantiomers have essentially the same activity against cancer cell lines with respect to the inhibition of replication, induction of apoptosis and inhibition of ABCB1. The central nervous system (CNS) receptor stereospecificity of (+) and (-)-TZ was first described by Svendsen et al. in 1988 [193]. Optical isomers such as those of TZ exhibit significant differences in their affinities for receptor sites, biotransformation and binding to serum and tissue proteins. Separation of the racemate TZ into its enantiomers in the human body has been measured [194]. In these investigations, the (-) enantiomer was found to be at higher concentrations than the (+) enantiomer in the different tissues. The general possibility for using the resolution of commercially available racemates in therapeutics for an anxiolytic effect has been described by Baumann et al. [195] and underlined by the very important investigations and statements made by Ariens et al. [196]. The role of the chirality of other compounds known to affect $\mathrm{ABCB} 1$, such as the enantiomers of verapamil, has been examined. These latter studies indicated that the $\mathrm{L}$ and the $\mathrm{D}$ forms of verapamil had equal abilities to reverse the in vitro resistance of MDR leukemic cells to drugs such as vincristine [197]. The mechanism of action of TZ has been analyzed in detail by Spengler et al., who showed that the racemate is able to induce the apoptosis of MDR mouse lymphoma cells [169]. In this latter study, the differential effects of the two TZ enantiomers were not examined. Nevertheless, the observations reported are consistent with those obtained by others on cervical and endometrial cancer cell lines [198]. In MDR cancer cells, the efflux pump mechanism is responsible for 
treatment failures; the inhibition of such mechanisms simultaneously with anticancer drugs may therefore result in effective anticancer chemotherapy. However, it must be considered that normal cells also contain ABC transporters, e.g. for detoxification. Hence, in order to avoid the toxic side-effect of resistance-reversing compounds, drugs with selective inhibition of the MDR in cancer cells are needed. To achieve this effect, three classes of known neuroleptic drugs with active and inactive stereoisomers were tested for MDR efflux pump inhibition on mouse Tlymphoma cell lines [199]. Their antiproliferative effects on sensitive and MDR cancer cell cultures were compared with those of the classical resistance modifier verapamil. Consistently with our present results, the enantiomers of phenylalkylamines proved to be equally potent inhibitors of drug transport by P-gp [199]. However, CNS-active and -inactive butaclamol enantiomers exerted slightly different effects on the reversal of the MDR phenotype, which means that drug binding might have weak enantioselectivity for P-gp [199], suggesting that some enantiomers of compounds that inhibit ABCB1 can be exploited as adjuvants to cytostatic chemotherapy of cancer in order to increase the efficacy of the cancer agent. However, in the current study, the separate use of one enantiomer of $\mathrm{TZ}$ versus the other did not appear to provide any advantage over racemic TZ for the adjuvant therapy of MDR cancer. 


\section{NEW FINDINGS}

- Aminoacylamide salts on the steroid skeleton exerted pronounced antiproliferative activity against MDR mouse T-lymphoma and LNCaP prostate cancer cell lines.

- Aminosteroids with basic primary amino groups had no anticancer effect.

- The $N$-hydroxyalkyl-2-aminophenothiazines substituted with secondary amines at position 2 in the ring and the oxidation state of the sulfur atom (sulfoxide or sulfone) influenced the antiproliferative activity on MDR colonic adenocarcinoma cells.

- A large number of substituted steroid compounds were able to enhance the activity of doxorubicin against the PC 3 cell line in combination experiments.

- $N$-hydroxyalkyl-2-aminophenothiazines containing secondary amines at position 2 in the ring, a 2-hydroxy group in the alkyl chain, and sulfoxide or sulfone had a synergistic effect with doxorubicin.

- No significant differences were found between the racemate and the (+) and (-) enantiomers of $\mathrm{TZ}$ as concerns antiproliferative activity against the MDR mouse T-lymphoma cell line.

- The separate use of one or other individual enantiomer did not appear to provide any advantage over use of the racemic mixture of TZ for the adjuvant therapy of MDR cancer.

- None of the substituted steroid derivatives or TZ compounds induced marked apoptosis either in PC3 prostate cancer cells or in MDR mouse T-lymphoma cells.

- Molecular docking is an effective computational technique which estimates the binding energy of a compound to the target protein. The tested steroid compounds proved to inhibit ABCB1 activity through binding to the drug-binding pocket, which is the same binding site as for verapamil. 


\section{SUMMARY}

The reason for unsuccessful tumor chemotherapy may be related to the MDR of tumor cells. One of the best known of these resistance mechanisms is the overexpression of membranebound efflux pumps, such as P-gp (ABCB1). In tumor cells, transport proteins eliminate various anticancer drugs from the intracellular space due to their flexible substrate binding site. One of the greatest challenges of anticancer chemotherapy at present is to find new, effective drugs to combat MDR. Amino- and amide-substituted steroid compounds and TZ derivatives are able to inhibit the activity of the ABCB1 (P-gp) efflux pump, and resistant cancer cells therefore become sensitive to anticancer drugs through modulation of the pump function. We examined the anticancer effects of steroid derivatives, stereoisomers of TZ and $N$-hydroxyalkyl-2aminophenothiazines in different in vitro models, such as sensitive and resistant mouse T-lymphoma cell lines, human prostate cancer and colon cancer cell lines. The antiproliferative and cytotoxic effects of steroid and phenothiazine compounds were studied by the MTT method on the L5178 mouse T-lymphoma parental cell line (PAR) and its L5178Y human ABCB1 genetransfected subline (MDR), hormone-sensitive $\mathrm{LNCaP}$ and hormone-resistant PC3 prostate cancer cell lines and MDR Colo 320 colon adenocarcinoma cells. The inhibitory effects of aminosteroid derivatives on the activity of the ABCB1 transporter protein were analyzed by the R123 accumulation assay in MDR mouse T-lymphoma cells through the use of flow cytometry. The interactions between doxorubicin and the examined compounds were also studied in the PC3 prostate cancer cell line and MDR Colo 320 colon adenocarcinoma cells, and the results were interpreted by means of Compusyn software. Aminoacylamide-substituted steroids exhibited marked antiproliferative activity against the MDR mouse T-lymphoma and LNCaP prostate cancer cell lines. Aminosteroids with basic primary amino groups did not exert anticancer effects on mouse T-lymphoma and prostate cancer cells. Despite the fact that the examined steroids did not display significant antiproliferative or cytotoxic effects on various cell lines, most of them potentiated the effect of doxorubicin on the PC3 prostate cancer cell line. In the case of $\mathrm{TZ}$, stereoisomerism did not play a role in blocking the ABCB1 transporter. Among the $\mathrm{N}$-hydroxyalkyl-2-aminophenothiazine derivatives, secondary amines exhibited antiproliferative effects on MDR colon adenocarcinoma cells, the extent depending on the oxidation state of the sulfur atom. Neither steroids nor TZ compounds influenced apoptosis in the PC3 prostate cancer cell line. To elucidate the structure-activity relationship between steroids and P-gp, molecular docking was used to estimate the binding energies of the compounds to the target protein. The tested steroids inhibited the ABCB1 activity through binding to the drug binding pocket, which is the same binding site as that for verapamil. 


\section{X. ÖSSZEFOGLALÓ}

A kemoterápia sikertelenségének oka a tumorsejtek multidrog rezisztencia (MDR) mechanizmusaihoz köthető. Ezek közül az egyik legismertebb a membránban lokalizálódó különböző efflux pumpák fokozott expressziója, például a P-glikoprotein (ABCB1) jelenléte. Tumorsejtekben ezek a transzporter fehérjék többféle, nem rokon szerkezetü rákellenes szert távolítanak el az intracelluláris térből, a flexibilis szubsztrátkötő-helyüknek köszönhetően. Korunk egyik égető problémája olyan új, hatékony vegyületek kifejlesztése, melyekkel képesek leszünk leküzdeni a tumorsejtek rezisztencia mechanizmusait. Az amino- és amido-csoportokkal szubsztituált szteroid vegyületek, valamint a különböző fenotiazin származékok képesek az ABCB1 (P-glikoprotein) efflux pumpát gátolni, így a multidrog rezisztens sejtek érzékennyé válnak a rákellenes szerekre. Vizsgálataink során ezen vegyületek antitumor hatását elemeztük érzékeny és rezisztens egér T-limfóma, hormon érzékeny és rezisztens humán prosztatarák és rezisztens humán vastagbélrák sejtvonalakon in vitro. Kísérleteink során a szteroid és fenotiazin vegyületek antiproliferatív és citotoxikus hatását vizsgáltuk MTT módszerrel érzékeny és rezisztens egér T-limfóma (PAR és MDR), hormon rezisztens PC3 és hormonra érzékeny LNCaP humán prosztatarák és Colo 320 humán vastagbélrák sejtvonalakon. Az ABCB1 transzporterre ható gátlást a rhodamin 123 intracelluláris akkumulációjával határoztuk meg rezisztens egér T-limfóma sejtvonalon, áramlási citometria segítségével. A doxorubicin és a vizsgált vegyületek közötti kölcsönhatást is vizsgáltuk PC3 és Colo 320 sejteken, ezen eredményeket CompuSyn software-rel intrepretáltuk.

Eredményeink alapján az aminoacil-amid szubsztituensek jelenléte a szteroid vázon jelentős rákellenes hatást mutatott $\mathrm{MDR}$ egér limfóma és $\mathrm{LNCaP}$ prosztatarák sejteken. Bázikus primer aminocsoportokat tartalmazó aminoszteroidok nem rendelkeztek rákellenes hatással egér limfóma és prosztatarák sejeken. Annak ellenére, hogy a vizsgált szteroid származékoknak nincs markáns antiproliferatív és citotoxikus hatása a vizsgált sejtvonalakon, doxorubicinnel kombinálva legtöbbjük potenciálja annak hatását PC3 humán prosztatarák sejtvonalon. Vizsgálataink alapján a szubsztituált szteroidok közül az aminoacil-amidoknak volt jelentősebb antiproliferatív hatása az MDR egér T-limfóma és LNCaP prosztatarák sejtvonalakon, az aminoszteroidok hatástalanok voltak. Az általunk vizsgált thioridazin vegyületek esetében a sztereoizomériának nem volt szerepe a tumorsejtek gátlásban. Az $N$-hidroxi-alkil-2-aminofenotiazin származékok közül a másodlagos aminoknak volt tumorellenes hatása MDR colon adenocarcinoma sejteken, az adott vegyületben lévő kén atom oxidációs állapotától függően. Sem a szteroid, sem a thioridazin vegyületek nem mutattak apoptózist indukáló hatást PC3 humán prosztatarák sejtvonal esetében. A szteroid vegyületek és a P-glikoprotein közötti szerkezet-hatás vizsgálatokat molekuláris docking technikával végeztük, amely a vegyület és a fehérje közötti kötési energiát határozza meg. A szteroidok gátló hatása az ABCB1 fehérje szubsztrátkötő zsebéhez való kapcsolódás által valósul meg, ehhez a helyhez kötődik a verapamil is. 


\section{REFERENCES}

1. Ferlay J, Soerjomataram I, Dikshit R, Eser S, Mathers C, Rebelo M, Parkin DM, Forman D, Bray F: Cancer incidence and mortality worldwide: sources, methods and major patterns in GLOBOCAN 2012. Int J Cancer. 136(5):359-386, 2015.

2. Bray F, Jemal A, Grey N, Ferlay J, Forman D: Global cancer transitions according to the Human Development Index (2008-2030): a population-based study. Lancet Oncol. 13(8):790-801, 2012.

3. Ferlay J, Steliarova-Foucher E, Lortet-Tieulent J, Rosso S, Coebergh JW, Comber H, Forman D and Bray F: Cancer incidence and mortality patterns in Europe: Estimates for 40 countries in 2012. Eur J Cancer. 49(6):1374-1403, 2013.

4. KSH (Központi Statisztikai Hivatal, Hungarian Central Statistical Office) data table: Death statistics by the most frequent causes of deaths (Halálozások a leggyakoribb halálokok szerint 1990-), refreshed on 08th August 2014. Internet access at http://portal.ksh.hu/pls/ksh/docs/hun/xstadat/ xstadat_eves/i_wnh001.htm

5. Liu H, Lv L, Yang K: Chemotherapy targeting cancer stem cells. Am J Cancer Res. 5(3):880-893, 2015.

6. Kasala ER, Bodduluru LN, Madana RM, V AK, Gogoi R, Barua CC: Chemopreventive and therapeutic potential of chrysin in cancer: mechanistic perspectives. Toxicol Lett. 233(2):214-225, 2015.

7. Shrotriya S, Agarwal R, Sclafani RA: A perspective on chemoprevention by resveratrol in head and neck squamous cell carcinoma. Adv Exp Med Biol. 815:333-348, 2015.

8. Rigas B, Tsioulias GJ: The evolving role of nonsteroidal anti-inflammatory drugs in colon cancer prevention: a cause for optimism. J Pharmacol Exp Ther. 353(1):2-8, 2015.

9. Tomasetti C. Drug resistance. Adv Exp Med Biol. 844:303-316, 2014.

10. Unger FT, Witte I, David KA: Prediction of individual response to anticancer therapy: historical and future perspectives. Cell Mol Life Sci. 72(4):729-757, 2015.

11. Ambudkar SV, Sauna ZE, Gottesman MM, Szakacs G: A novel way to spread drug resistance in tumor cells: functional intercellular transfer of P-glycoprotein (ABCB1). Trends Pharmacol Sci. 26(8):385-387, 2005.

12. Gatti L, Beretta GL, Cossa G, Zunino F, Perego P: ABC transporters as potential targets for modulation of drug resistance. Mini Rev Med Chem. 9(9):1102-1112, 2009.

13. Nasr AL: Combination of chemotherapy and surgery in the treatment of cancer. Acta Unio Int Contra Cancrum. 19:1108-1111, 1963.

14. Sheps JA, Ling V: Preface: the concept and consequences of multidrug resistance. Pflugers Arch. 453(5):545-553, 2007.

15. Ahmed KA, Xiang J: Mechanisms of cellular communication through intercellular protein transfer. J Cell Mol Med. 15(7):1458-1473, 2011. 
16. Cui J, Li S: Inhibitors and prodrugs targeting CYP1: a novel approach in cancer prevention and therapy. Curr Med Chem. 21(5):519-552, 2014.

17. Tevyashova AN, Olsufyeva EN, Preobrazhenskaya MN: Design of dual action antibiotics as an approach to search for new promising drugs. Russian Chemical Reviews. 84(1):61, 2015.

18. Balar AV, Milowsky MI: Cytotoxic and DNA-targeted therapy in urothelial cancer: have we squeezed the lemon enough? Cancer. 121(2):179-187, 2015.

19. Zheng Y, Dou Y, Duan L, Cong C, Gao A, Lai Q, Sun Y: Using chemo-drugs or irradiation to break immune tolerance and facilitate immunotherapy in solid cancer. Cell Immunol. 294(1):54-59, 2015.

20. Blok EJ, Derks MG, van der Hoeven JJ, van de Velde CJ, Kroep JR:Extended adjuvant endocrine therapy in hormone-receptor positive early breast cancer:current and future evidence. Cancer Treat Rev. 41(3):271-276, 2015.

21. Zahreddine H, Borden KL: Mechanisms and insights into drug resistance in cancer. Front Pharmacol. 4:28, 2013.

22. Gottesman MM: Mechanisms of cancer drug resistance. Annu Rev Med. 53:615-627, 2002.

23. Saraswathy M, Gong S: Different strategies to overcome multidrug resistance in cancer. Biotechnol Adv. 31(8):1397-1407, 2013.

24. Chen KG, Sikic BI: Molecular pathways: regulation and therapeutic implications of multidrug resistance. Clin Cancer Res. 18(7):1863-1869, 2012.

25. Huang L, Perrault C, Coelho-Martins J, Hu C, Dulong C, Varna M, Liu J, Jin J, Soria C, Cazin L, Janin A, Li H, Varin R, Lu H: Induction of acquired drug resistance in endothelial cells and its involvement in anticancer therapy. J Hematol Oncol. 6:49, 2013.

26. Zdrazil B, Chichester C, Zander Balderud L, Engkvist O, Gaulton A, Overington JP: Transporter assays and assay ontologies: useful tools for drug discovery. Drug Discov Today Technol. 12:4754, 2014.

27. Nigam SK: What do drug transporters really do? Nat Rev Drug Discov. 14(1):29-44, 2015.

28. Yu P, Cheng X, Du Y, Yang L, Huang L: Significance of MDR-related proteins in the postoperative individualized chemotherapy of gastric cancer. J Cancer Res Ther. 11(1):46-50, 2015.

29. Popeda M, Pluciennik E, Bednarek AK:Proteins in cancer multidrug resistance. Postepy Hig Med Dosw. 68:616-632, 2014.

30. Gustavsson B, Carlsson G, Machover D, Petrelli N, Roth A, Schmoll HJ, Tveit KM, Gibson F: A review of the evolution of systemic chemotherapy in the management of colorectal cancer. Clin Colorectal Cancer. 14(1):1-10, 2015.

31. Bailly C: Anticancer properties of lamellarins. Mar Drugs. 13(3):1105-1123, 2015.

32. Gravina GL, Senapedis W, McCauley D, Baloglu E, Shacham S, Festuccia C: Nucleo-cytoplasmic transport as a therapeutic target of cancer. J Hematol Oncol. 7:85, 2014.

33. Labi V, Erlacher M: How cell death shapes cancer. Cell Death Dis. 6:1675, 2015. 
34. Goldar S, Khaniani MS, Derakhshan SM, Baradaran B: Molecular Mechanisms of Apoptosis and Roles in Cancer Development and Treatment. Asian Pac J Cancer Prev. 16(6):2129-2144, 2015.

35. Gajate C, Mollinedo F: Lipid rafts and Fas/CD95 signaling in cancer chemotherapy. Recent Pat Anticancer Drug Discov. 6(3):274-283, 2011.

36. Chai S, To KK, Lin G: Circumvention of multi-drug resistance of cancer cells by Chinese herbal medicines. Chin Med. 5:26, 2010.

37. Trimble WS, Grinstein S: Barriers to the free diffusion of proteins and lipids in the plasma membrane. J Cell Biol. 208(3):259-271, 2015.

38. Leslie EM, Deeley RG, Cole SP: Multidrug resistance proteins: role of P-glycoprotein, MRP1, MRP2, and BCRP (ABCG2) in tissue defense. Toxicol Appl Pharmacol. 204(3):216-237, 2005.

39. Denning EJ, Beckstein O: Influence of lipids on protein-mediated transmembrane transport. Chem Phys Lipids. 169:57-71, 2013.

40. Wang Y, Shaikh SA, Tajkhorshid E: Exploring transmembrane diffusion pathways with molecular dynamics. Physiology (Bethesda). 25(3):142-154, 2010.

41. Ling V, Thompson LH: Reduced permeability in CHO cells as a mechanism of resistance to colchicine. J Cell Physiol. 83(1):103-116, 1974.

42. Thiebaut F, Tsuruo T, Hamada H, Gottesman MM, Pastan I, Willingham MC: Cellular localization of the multidrug-resistance gene product P-glycoprotein in normal human tissues. Proc Natl Acad Sci USA. 84(21):7735-7738, 1987.

43. Cordon-Cardo C, O'Brien JP, Casals D., Rittman-Grauer L, Biedler JL, Melamed MR: Multidrugresistance gene (P-glycoprotein) is expressed by endothelial cells at blood-brain barrier sites. Proc Natl Acad Sci USA. 86(2):695-698, 1989.

44. Kawai K, Kusano I, Ido M, Sakurai M, Shiraishi T, Yatani R: Identification of a P-glycoproteinrelated protein (mini-P-glycoprotein) which is overexpressed in multidrug resistant cells. Biochem Biophys Res Commun. 198(2):804-810, 1994.

45. Young LC, Campling BG, Cole SP, Deeley RG, Gerlach JH: Multidrug resistance proteins MRP3, MRP1, and MRP2 in lung cancer: correlation of protein levels with drug response and messenger RNA levels. Clin Cancer Res. 7(6):1798-1804, 2001.

46. Maliepaard M, van Gastelen MA, de Jong LA, Pluim D, van Waardenburg RC, Ruevekamp-Helmers MC, Floot BG, Schellens JH: Overexpression of the BCRP/MXR/ABCP gene in a topotecanselected ovarian tumor cell line. Cancer Res. 59(18):4559-4563, 1999.

47. Davidson AL, Dassa E, Orelle C, Chen J: Structure, function, and evolution of bacterial ATPbinding cassette systems. Microbiol Mol Biol Rev. 72(2):317-364, 2008.

48. Szakacs G, Paterson JK, Ludwig JA, Booth-Genthe C, Gottesman MM: Targeting multidrug resistance in cancer. Nat Rev Drug Discov. 5(3):219-234, 2006. 
49. Szakacs G, Varadi A, Ozvegy-Laczka C, Sarkadi B: The role of ABC transporters in drug absorption, distribution, metabolism, excretion and toxicity (ADME-Tox).Drug Discov Today. 13(9-10):379-393, 2008.

50. Glavinas H, Krajcsi P, Cserepes J, Sarkadi B: The role of ABC transporters in drug resistance, metabolism and toxicity. Curr Drug Deliv. 1(1):27-42, 2004.

51. Stavrovskaya AA, Stromskaya TP: Transport proteins of the ABC family and multidrug resistance of tumor cells. Biochemistry (Mosc). 73(5):592-604, 2008.

52. Sarkadi B, Homolya L, Szakacs G, Varadi A: Human multidrug resistance ABCB and ABCG transporters: participation in a chemoimmunity defense system.Physiol Rev. 86(4):1179-1236, 2006.

53. Hollo Z, Homolya L, Hegedus T, Muller M, Szakacs G, Jakab K, Antal F, Sarkadi B: Parallel functional and immunological detection of human multidrug resistance proteins, P-glycoprotein and MRP1. Anticancer Res. 18(4C):2981-2987, 1998.

54. Poguntke M, Hazai E, Fromm MF, Zolk O: Drug transport by breast cancer resistance protein. Expert Opin Drug Metab Toxicol. 6(11):1363-1384, 2010.

55. Seeger MA, van Veen HW: Molecular basis of multidrug transport by ABC transporters. Biochim Biophys Acta. 1794(5):725-737, 2009.

56. Sarkadi B, Muller M, Hollo Z: The multidrug transporters-proteins of an ancient immune system. Immunol Lett. 54(2-3):215-219, 1996.

57. Brozik A, Hegedus C, Erdei Z, Hegedus T, Ozvegy-Laczka C, Szakacs G, Sarkadi B: Tyrosine kinase inhibitors as modulators of ATP binding cassette multidrug transporters: substrates, chemosensitizers or inducers of acquired multidrug resistance? Expert Opin Drug Metab Toxicol. 7(5):623-642, 2011.

58. Sarkadi B, Homolya L, Szakács G, Váradi A: Human multidrug resistance ABCB and ABCG transporters: participation in a chemoimmunity defense system. Physiol Rev. 86(4):1179-1236, 2006.

59. Marcoux J, Wang SC, Politis A, Reading E, Ma J, Biggin PC, Zhou M, Tao H, Zhang Q, Chang G, Morgner N, Robinson CV: Mass spectrometry reveals synergistic effects of nucleotides, lipids, and drugs binding to a multidrug resistance efflux pump. Proc Natl Acad Sci USA. 110(24):9704-9709, 2013.

60. Abdallah HM, Al-Abd AM, El-Dine RS, El-Halawany AM: P-glycoprotein inhibitors of natural origin as potential tumor chemo-sensitizers: A review. J Adv Res. 6(1):45-62, 2015.

61. Lage H: An overview of cancer multidrug resistance: a still unsolved problem. Cell Mol Life Sci. 65(20):3145-3167, 2008.

62. Sharom FJ: Complex interplay between the P-glycoprotein multidrug efflux pump and the membrane: its role in modulating protein function. Front Oncol. 4:41, 2014. 
63. Alvarez AI, Real R, Perez M, Mendoza G, Prieto JG, Merino G: Modulation of the activity of ABC transporters (P-glycoprotein, MRP2, BCRP) by flavonoids and drug response. J Pharm Sci. 99(2):598-617, 2010.

64. Wesolowska O: Interaction of phenothiazines, stilbenes and flavonoids with multidrug resistanceassociated transporters, P-glycoprotein and MRP1. Acta Biochim Pol. 58(4):433-448, 2011.

65. Nobili S, Landini I, Mazzei T, Mini E: Overcoming tumor multidrug resistance using drugs able to evade P-glycoprotein or to exploit its expression. Med Res Rev. 32(6):1220-1262, 2012.

66. Klepsch F, Stockner T, Erker T, Muller M, Chiba P, Ecker GF:Using structural and mechanistic information to design novel inhibitors/substrates of P-glycoprotein. Curr Top Med Chem. 10(17):1769-1774, 2010.

67. Tsuruo T, Iida H, Kitatani Y, Yokota K, Tsukagoshi S, Sakurai Y: Effects of quinidine and related compounds on cytotoxicity and cellular accumulation of vincristine and adriamycin in drug-resistant tumor cells. Cancer Res. 44(10):4303-4307, 1984.

68. Zhu F, Zheng CJ, Han LY, Xie B, Jia J, Liu X, Tammi MT, Yang SY, Wei YQ, Chen YZ:Trends in the exploration of anticancer targets and strategies in enhancing the efficacy of drug targeting. Curr Mol Pharmacol. 1(3):213-232, 2008.

69. Dantzig AH, de Alwis DP, Burgess M: Considerations in the design and development of transport inhibitors as adjuncts to drug therapy. Adv Drug Deliv Rev. 55(1):133-150, 2003.

70. Mao Z, Zhou J, Luan J, Sheng W, Shen X, Dong X: Tamoxifen reduces P-gp-mediated multidrug resistance via inhibiting the PI3K/Akt signaling pathway in ER-negative human gastric cancer cells. Biomed Pharmacother. 68(2):179-183, 2014.

71. Colabufo NA, Berardi F, Perrone MG, Capparelli E, Cantore M, Inglese C, Perrone R: Substrates, inhibitors and activators of P-glycoprotein: candidates for radiolabeling and imaging perspectives. Curr Top Med Chem. 10(17):1703-1714, 2010.

72. Kapse-Mistry S, Govender T, Srivastava R, Yergeri M: Nanodrug delivery in reversing multidrug resistance in cancer cells. Front Pharmacol. 5:159, 2014.

73. Wilson WH, Bates SE, Fojo A, Bryant G, Zhan Z, Regis J, Wittes RE, Jaffe ES, Steinberg SM, Herdt J:Controlled trial of dexverapamil, a modulator of multidrug resistance, in lymphomas refractory to EPOCH chemotherapy. J Clin Oncol. 13(8):1995-2004, 1995.

74. Chapman JV, Gouaze-Andersson V, Karimi R, Messner MC, Cabot MC: P-glycoprotein antagonists confer synergistic sensitivity to short-chain ceramide in human multidrug-resistant cancer cells. Exp Cell Res. 317(12):1736-1745, 2011.

75. Palmeira A, Sousa E, Vasconcelos MH, Pinto MM:Three decades of P-gp inhibitors: skimming through several generations and scaffolds. Curr Med Chem. 19(13):1946-2025, 2012.

76. Ozben T: Mechanisms and strategies to overcome multiple drug resistance in cancer. FEBS Lett. 580(12):2903-2909, 2006. 
77. Fox E, Bates SE: Tariquidar (XR9576): a P-glycoprotein drug efflux pumpinhibitor. Expert Rev Anticancer Ther. 7(4):447-459, 2007.

78. Thomas H, Coley HM: Overcoming multidrug resistance in cancer: an update on the clinical strategy of inhibiting p-glycoprotein. Cancer Control. 10(2):159-165, 2003.

79. Patil Y, Sadhukha T, Ma L, Panyam J: Nanoparticle-mediated simultaneous and targeted delivery of paclitaxel and tariquidar overcomes tumor drug resistance. J Control Release. 136(1):21-29, 2009.

80. Yamagishi T, Sahni S, Sharp DM, Arvind A, Jansson PJ, Richardson DR:P-glycoprotein mediates drug resistance via a novel mechanism involving lysosomal sequestration. J Biol Chem. 288(44):31761-31771, 2013.

81. Pick A, Muller H, Wiese M: Structure-activity relationships of new inhibitors of breast cancer resistance protein (ABCG2). Bioorg Med Chem. 16(17):8224-8236, 2008.

82. Chang C, Lee SO, Yeh S, Chang TM: Androgen receptor (AR) differential roles in hormone-related tumors including prostate, bladder, kidney, lung, breast and liver. Oncogene. 33(25):3225-3234, 2014.

83. Pintér O, Pajor L, Molnár J, Márki A, Falkay G: The role of androgen receptors in the dynamic process of prostate cancer: their analytical determination in biopsy material. In Vivo. 18(6):809-812, 2004.

84. Huggins C, Masina MH, Eichelberger L, Wharton JD: Quantitative studies of prostatic secretion: I. Characteristic of the normal secretion; The influence of thyroid, suprarenal, and testis extirpation and androgen substitution on the prostatic output. J Exp Med. 70(6):543-556, 1939.

85. Cavalieri EL, Rogan EG: Depurinating estrogen-DNA adducts in the etiology and prevention of breast and other human cancers. Future Oncol. 6(1):75-91, 2010.

86. Gaikwad N, Yang L, Weisenburger DD, Vose J, Beseler C, Rogan EG, Cavalieri EL: Urinary biomarkers suggest that estrogen-DNA adducts may play a role in the etiology of non-Hodgkin lymphoma. Biomarkers. 14(7):502-512, 2009.

87. Weiderpass E, Meo M, Vainio H: Risk factors for breast cancer, including occupational exposures. Saf Health Work. 2(1):1-8, 2011.

88. Olsen NJ, Kovacs WJ: Gonadal steroids and immunity.Endocr. Rev. 17(4):369-384,1996.

89. Hoover RN: Lymphoma risks in populations with altered immunity-a search for a mechanism.Cancer Res. 52(19 Suppl):5477-5478,1992.

90. Li JJ: Perspectives in hormonal carcinogenesis: animal models to human disease.Prog Clin Biol Res. 394:447-454,1996.

91. Beral V, Banks E, Reeves G, Appleby P: Use of HRT and the subsequent risk of cancer. J Epidemiol Biostat. 4(3):191-210, 1999.

92. La Vecchia C, Franceschi S: Reproductive factors and colorectal cancer. Cancer Causes Control. 2(3):193-200, 1991. 
93. Fernandez E, La Vecchia C, Balducci A, Chatenoud L, Franceschi S, Negri E: Oral contraceptives and colorectal cancer risk: a meta-analysis. Br J Cancer. 84(5):722-727, 2001.

94. Grodstein F, Newcomb PA, Stampfer MJ: Postmenopausal hormone therapy and the risk of colorectal cancer: a review and meta-analysis. Am J Med. 106(5):574-582, 1999.

95. Singh P, Velasco M, Given R, Varro A, Wang TC: Progastrin expression predisposes mice to colon carcinomas and adenomas in response to a chemical carcinogen. Gastroenterology. 119(1):162-171, 2000.

96. Wang TC, Koh TJ, Varro A, Cahill RJ, Dangler CA, Fox JG, Dockray GJ: Processing and proliferative effects of human progastrin in transgenic mice. J Clin Invest. 98(8):1918-1929, 1996.

97. Hollande F, Lee DJ, Choquet A, Roche S, Baldwin GS: Adherens junctions and tight junctions are regulated via different pathways by progastrin in epithelial cells. J Cell Sci. 116(7):1187-1197, 2003.

98. Singh P, Lu X, Cobb S, Miller BT, Tarasova N, Varro A, Owlia A: Progastrin1-80 stimulates growth of intestinal epithelial cells in vitro via high-affinity binding sites. Am J Physiol Gastrointest Liver Physiol. 284(2):328-339, 2003.

99. Umar S, Sarkar S, Cowey S, Singh P: Activation of NF-kappaB is required for mediating proliferative and antiapoptotic effects of progastrin on proximal colonic crypts of mice, in vivo. Oncogene. 27(42):5599-5611, 2008.

100. Ferrand A, Bertrand C, Portolan G, Cui G, Carlson J, Pradayrol L, Fourmy D, Dufresne M, Wang TC, Seva C: Signaling pathways associated with colonic mucosa hyperproliferation in mice overexpressing gastrin precursors. Cancer Res. 65(7):2770-2777, 2005.

101. Ferrand A, Wang TC: Gastrin and cancer: a review. Cancer Lett. 238(1):15-29, 2006.

102. Bertrand C, Kowalski-Chauvel A, Do C, Résa C, Najib S, Daulhac L, Wang TC, Ferrand A, Seva C: A gastrin precursor, gastrin-gly, upregulates VEGF expression in colonic epithelial cells through an HIF-1-independent mechanism. Int J Cancer. 126(12):2847-2857, 2010.

103. Grabowska AM, Hughes J, Watson SA: Use of interfering RNA to investigate the role of endogenous gastrin in the survival of gastrointestinal cancer cells. Br J Cancer. 96(3):464-473, 2007.

104. Radogna F, Dicato M, Diederich M: Cancer-type-specific crosstalk between autophagy, necroptosis and apoptosis as a pharmacological target. Biochem Pharmacol. 94(1):1-11, 2015.

105. Nagasaka A, Kawane K, Yoshida H, Nagata S: Apaf-1-independent programmed cell death in mouse development. Cell Death Differ. 17(6):931-941, 2010.

106. Burgess DJ: Apoptosis: Refined and lethal. Nat Rev Canc. 13(2):79, 2013.

107. Verbrugge I, Johnstone RW, Smyth MJ: SnapShot: extrinsic apoptosis pathways. Cell. 143(7):1192, 2010.

108. Tian H, Gao Z, Li H, Zhang B, Wang G, Zhang Q, Pei D, Zheng J: DNA damage response-a double-edged sword in cancer prevention and cancer therapy. Cancer Lett. 358(1):8-16, 2015. 
109. Gravina GL, Marampon F, Sherris D, Vittorini F, Di Cesare E, Tombolini V, Lenzi A, Jannini EA, Festuccia C: Torc1/Torc2 inhibitor, Palomid 529, enhances radiation response modulating CRM1mediated survivin function and delaying DNA repair in prostate cancer models. Prostate. 74(8):852-868, 2014.

110. Turner JG, Sullivan DM: CRM1-mediated nuclear export of proteins and drug resistance in cancer. Curr Med Chem. 15(26):2648-2655, 2008.

111. Mirski SE, Sparks KE, Friedrich B, Kohler M, Mo YY, Beck WT, Cole SP: Topoisomerase II binds importin alpha isoforms and exportin/CRM1 but does not shuttle between the nucleus and cytoplasm in proliferating cells. Exp Cell Res. 313(3):627-637, 2007.

112. Abraham SA, Holyoake TL: Redirecting traffic using the XPO1 police. Blood. 122(17):29262928, 2013.

113. Ohtani N, Brennan P, Gaubatz S, Sanij E, Hertzog P, Wolvetang E, Ghysdael J, Rowe M, Hara E: Epstein-Barr virus LMP1 blocks p16INK4a-RB pathway by promoting nuclear export of E2F4/5. J Cell Biol. 162(2):173-183, 2003.

114. Henderson BR: Nuclear-cytoplasmic shuttling of APC regulates beta-catenin subcellular localization and turnover. Nat Cell Biol. 2(9):653-660, 2000.

115. Santiago A, Li D, Zhao LY, Godsey A, Liao D: p53 SUMOylation promotes its nuclear export by facilitating its release from the nuclear export receptor CRM1. Mol Biol Cell. 24(17):2739-2752, 2013.

116. Alt JR, Gladden AB, Diehl JA: p21 (Cip1) Promotes cyclin D1 nuclear accumulation via direct inhibition of nuclear export. J Biol Chem. 277(10):8517-8523, 2002.

117. Wang Y, Wang Y, Xiang J, Ji F, Deng Y, Tang C, Yang S, Xi Q, Liu R, Di W: Knockdown of CRM1 inhibits the nuclear export of p27(Kip1) phosphorylated at serine 10 and plays a role in the pathogenesis of epithelial ovarian cancer. Cancer Lett. 343(1):6-13, 2014.

118. Yashiroda Y, Yoshida M: Nucleo-cytoplasmic transport of proteins as a target for therapeutic drugs. Curr Med Chem. 10(9):741-748, 2003.

119. Niu M, Wu S, Mao L, Yang Y: CRM1 is a cellular target of curcumin: new insights for the myriad of biological effects of an ancient spice. Traffic. 14(10):1042-1052, 2013.

120. Su Z, Yang Z, Xu Y, Chen Y, Yu Q: Apoptosis, autophagy, necroptosis, and cancer metastasis. Mol Cancer. 14(1):48, 2015.

121. Sochalska M, Tuzlak S, Egle A, Villunger A: Lessons from gain- and loss-of-function models of pro-survival Bcl2 family proteins: implications for targeted therapy. FEBS J. 282(5):834-849, 2015.

122. Farooqi AA, Butt G, Yousaf G, Qadir MI, Shaukat U, Mansoor Q, Awan M, Bhatti S, Begum A: Making personalized prostate cancer medicine a reality: challenges and opportunities in the reestablishment of gold standards. Pak J Pharm Sci. 26(4):831-840, 2013. 
123. Gerritse FL, Meulenbeld HJ, Roodhart JM, van der Velden AM, Blaisse RJ, Smilde TJ, Erjavec Z, de Wit R, Los M: Analysis of docetaxel therapy in elderly ( $\geq 70$ years) castration resistant prostate cancer patients enrolled in the Netherlands Prostate Study. Eur J Cancer. 49(15):3176-3183, 2013.

124. Bray F, Ferlay J, Forman D, Lortet-Tieulent J and Auvinen A: Prostate cancer incidence and mortality trends in 37 European countries. Eur J of Cancer. 46(17):3040-3052, 2010.

125. Géczi L, Sinkovics I: Bone-targeted treatment in prostate cancer. Hung Oncol. 58(3):199-203, 2014.

126. Sapi Z, Bodo M, Vadasz G, Henson DEandHaas GP: The increasing incidence of prostate cancer in Hungary. In Vivo. 8(3):433-436, 1994.

127. Song JY, Yu J, Chan WC. Gene expression profiling in non-Hodgkin lymphomas. Cancer Treat Res. 165:97-123, 2015.

128. Soldini D, Campo E: New insights into the diagnosis of lymphomas. Ann Oncol. 23(10):83-88, 2012

129. Siegel R, DeSantis C, Virgo K, Stein K, Mariotto A, Smith T, Cooper D, Gansler T, Lerro C, Fedewa S, Lin C, Leach C, Cannady RS, Cho H, Scoppa S, Hachey M, Kirch R, Jemal A, Ward E: Cancer treatment and survivorship statistics. 2012 CA Cancer J Clin. 62(4), 220-241, 2012.

130. Center MM, Jemal A, Smith RA, Ward E: Worldwide variations in colorectal cancer. CA Cancer J Clin. 59(6), 366-378, 2009.

131. Center MM, Jemal A, Ward E: International trends in colorectal cancer incidence rates. Cancer Epidemiol Biomarkers Prev. 18(6), 1688-1694, 2009.

132. Stock C, Pulte D, Haug U, Brenner H: Subsite-specific colorectal cancer risk in the colorectal endoscopy era. Gastrointest Endosc. 75(3):621-630, 2012.

133. Catalona WJ, Richie JP, Ahmann FR, Hudson MA, Scardino PT, Flanigan RC, Dekernion JB, Ratliff TL, Kavoussi LR and Dalkin BL: Comparison of digital rectal examination and serum prostate specific antigen in the early detection of prostate cancer: results of a multicenter clinical trial of 6,630 men. J Urol. 151(5):1283-1290, 1994.

134. Pfister D, Heidenreich A, Porres D: Biomarker docetaxel-based chemotherapy. Urologe A. 52(9):1261-1264, 2013.

135. Pintér O, Mucsi I, Molnár J: In vitro antiproliferation in prostate cancer cell lines with cytostatics and combinations with resistance modifiers. In Vivo. 19(1):253-259, 2005.

136. Tanner MJ, Welliver RC Jr, Chen M, Shtutman M, Godoy A, Smith G, Mian BM, Buttyan R: Effects of androgen receptor and androgen on gene expression in prostate stromal fibroblasts and paracrine signaling to prostate cancer cells. PLoS One. 6(1):16027, 2011.

137. Mohler JL, Titus MA, Wilson EM: Potential prostate cancer drug target: bioactivation of androstanediol by conversion to dihydrotestosterone. Clin Cancer Res. 17(18):5844-5849, 2011.

138. Sternberg CN, Castellano D, Daugaard G, Géczi L, Hotte SJ, Mainwaring PN, Saad F, Souza C, Tay MH, Garrido JM, Galli L, Londhe A, De Porre P, Goon B, Lee E,McGowan T, Naini V, Todd 
MB, Molina A, George DJ: Abiraterone Global EAP Investigators. Abiraterone acetate for patients with metastatic castration-resistant prostate cancer progressing after chemotherapy: final analysis of a multicentre, open-label, early-access protocol trial. Lancet Oncol. 15(11):1263-1268, 2014.

139. Cha EK, Eastham JA: Chemotherapy and novel therapeutics before radical prostatectomy for highrisk clinically localized prostate cancer. Urol Oncol. 33(5):217-225, 2015.

140. Intlekofer AM, Younes A: Precision therapy for lymphoma-current state and future directions. Nat Rev. 11(10):585-596, 2014

141. Linnekamp JF, Wang X, Medema JP, Vermeulen L: Colorectal cancer heterogeneity and targeted therapy: a case for molecular disease subtypes. Cancer Res. 75(2):245-249, 2015.

142. Brenner H, Kloor M, Pox CP: Colorectal cancer. Lancet. 383(9927):1490-1502, 2014.

143. Lakatos PL, Lakatos L: Risk for colorectal cancer in ulcerative colitis: changes, causes and management strategies.World J Gastroenterol. 14(25):3937-3947, 2008.

144. Guzzetta AA, Pisanic Ii TR, Sharma P, Yi JM, Stark A, Wang TH, Ahuja N: The promise of methylation on beads for cancer detection and treatment. Expert Rev Mol Diagn. 14(7):845-852, 2014.

145. Zhang ZG, Harstrick A, Rustum YM: Mechanisms of resistance to fluoropyrimidines. Semin Oncol. 19(2-3):4-9, 1992.

146. Petrelli N, Douglass HO, Herrera L, Russell D, Stablein DM, Bruckner HW, Mayer RJ, Schinella R, Green MD, Muggia FM: The modulation of fluorouracil with leucovorin in metastatic colorectal carcinoma: a prospective randomized phase III trial. Gastrointestinal Tumor Study Group. J Clin Oncol. 7(10):1419-1426, 1989.

147. Rabik CA, Dolan ME: Molecular mechanisms of resistance and toxicity associated with platinating agents. Cancer Treat Rev. 33(1):9-23, 2007.

148. Borden KL: When will resistance be futile? Cancer Res. 74(24):7175-7180, 2014.

149. Biellmann JF: Enantiomeric steroids: synthesis, physical, and biological properties. Chem Rev. 103(5):2019-2033, 2003.

150. Gomez L, Kovac JR, Lamb DJ: CYP17A1 inhibitors in castration-resistant prostate cancer. Steroids. 95:80-87, 2015.

151. Leyssens C, Marien E, Verlinden L, Derua R, Waelkens E, Swinnen JV, Verstuyf A: Remodeling of phospholipid composition in colon cancer cells by $1 \alpha, 25(\mathrm{OH}) 2 \mathrm{D} 3$ and its analogs. J Steroid Biochem Mol Biol. 148:172-178, 2015.

152. Guleria A, Jangid DK, Gautam N, Lakhotia R, Chowdhary A, Gautam DC: Synthesis and antitubercular screening of some novel $4 \mathrm{H}-1,4-$ benzothiazines and their sulfones under environment benign solvent free conditions as future anti-tubercular agents. Comb Chem High Throughput Screen. 18(1):48-52, 2015.

153. Motohashi N, Kawase M, Satoh K, Sakagami H: Cytotoxic potential of phenothiazines. Curr Drug Targets. 7(9):1055-1066, 2006. 
154. Dasgupta A, Jeyaseeli L, Dutta NK, Mazumdar K, Karak P, Dastidar SG, Motohashi N, Shirataki Y: Studies on the antimicrobial potential of the cardiovascular drug lacidipine. In Vivo. 21(5):847850, 2007.

155. Gaye-Seye MD, Aaron JJ, Parkanyi C, Motohashi N: Luminescence and photophysical properties of benzo[a]phenothiazines-therapeutic, physico-chemical, and analytical applications. Curr Drug Targets. 7(9):1083-1093, 2006.

156. Molnar J, Molnar A, Mucsi I, Pinter O, Nagy B, Varga A, Motohashi N. Reversal of multidrug resistance in mouse lymphoma cells by phenothiazines. In Vivo. 17(2):145-149, 2003.

157. Pluta K, Morak-Mlodawska B, Jelen M: Recent progress in biological activities of synthesized phenothiazines. Eur J Med Chem. 46(8):3179-3189, 2011.

158. Sagar PS, Das UN, Koratkar R, Ramesh G, Padma M, Kumar GS: Cytotoxic action of cis-unsaturated fatty acids on human cervical carcinoma (HeLa) cells: relationship to free radicals and lipid peroxidation and its modulation by calmodulin antagonists. Cancer Lett. 63(3):189-198, 1992.

159. Darkin S, McQuillan J, Ralph RK: Chlorpromazine: a potential anticancer agent? Biochem Biophys Res Commun. 125(1):184-191, 1984.

160. Hait WN, Gesmonde JF, Lazo JS: Effect of anti-calmodulin drugs on the growth and sensitivity of C6 rat glioma cells to bleomycin. Anticancer Res. 14(5A):1711-1721, 1994.

161. Jones GR: Successful cancer therapy with promethazine: the rationale. Med Hypotheses. 46(1):2529, 1996.

162. Rho SB, Kim BR, Kang S: A gene signature-based approach identifies thioridazine as an inhibitor of phosphatidylinositol-3'-kinase (PI3K)/AKT pathway in ovarian cancer cells. Gynecol Oncol. 120(1):121-127, 2011.

163. Strobl JS, Peterson VA: Tamoxifen-resistant human breast cancer cell growth: inhibition by thioridazine, pimozide and the calmodulin antagonist, W-13. J Pharmacol Exp Ther. 263(1):186193, 1992.

164. Mayur YC, Peters GJ, Prasad VV, Lemo C, Sathish NK: Design of new drug molecules to be used in reversing multidrug resistance in cancer cells. Curr Cancer Drug Targets. 9(3):298-306, 2009.

165. Rodriguez-Mora O, LaHair MM, Howe CJ, McCubrey JA, Franklin RA: Calcium/calmodulindependent protein kinases as potential targets in cancer therapy. Expert Opin Ther Targets. 9(4):791-808, 2005.

166. Amaral L, Kristiansen JE, Abebe LS, Millett W: Inhibition of the respiration of multidrug-resistant clinical isolates of Mycobacterium tuberculosis by thioridazine: potential use for initial therapy of freshly diagnosed tuberculosis. J Antimicrob Chemother. 38(6):1049-1053, 1996.

167. Spengler G, Evaristo M, Handzlik J, Serly J, Molnar J, Viveiros M, Kiec-Kononowicz K, Amaral L: Biological activity of hydantoin derivatives on P-glycoprotein (ABCB1) of mouse lymphoma cells. Anticancer Res. 30(12):4867-4871, 2010. 
168. Spengler G, Viveiros M, Martins M, Rodrigues L, Martins A, Molnar J, Couto I, Amaral L: Demonstration of the activity of P-glycoprotein by a semi-automated fluorometric method. Anticancer Res. 29(6):2173-2177, 2009.

169. Spengler G, Molnar J, Viveiros M, Amaral L: Thioridazine induces apoptosis of multidrugresistant mouse lymphoma cells transfected with the human ABCB1 and inhibits the expression of P-glycoprotein. Anticancer Res. 31(12):4201-4205, 2011.

170. Jaszczyszyn A, Gasiorowski K, Swiatek P, Malinka W, Cieslik-Boczula K, Petrus J, CzarnikMatusewicz B: Chemical structure of phenothiazines and their biological activity. Pharmacol Rep. 64(1):16-23, 2012.

171. Szendi Z, Dombi G, Vincze I: Steroids, LIII: New routes to aminosteroids. Monatshefte für Chemie 127: 1189-1196, 1996.

172. Vincze I, Hackler L, Szendi S, Schneider G: Steroids 54. Amino acylamidosteroids. Steroids 61(12):697-702, 1996.

173. Vincze I, Somlai Cs, Schneider Gy, Dombi Gy, Mák M: Steroids. XLV. Neighbouring group participation. XII. Decomposition of (Z)-16-amidomethylene-17b-hydroxy steroids mediated by neighbouring group participation. Liebigs Annalen der Chemie 3:187-192, 1992.

174. Forgo P, Vincze I: Syntheses and advanced NMR structure determination of androsteno-[17,16d]-pyrimidine derivatives. Steroids 67(9):749-756, 2002.

175. Serly J, Vincze I, Somlai Cs, Hodonicki L, Molnár J: Synthesis and comparison of the antitumor activities of steroids on $A B C B 1$-transfected mouse lymphoma and human ovary carcinoma. Lett Drug Des Discov. 8:138-147, 2011.

176. Bourquin JP, Schwarb G, Gamboni G, Fischer R, Ruesch L, Guldimann S, Theus V, Schenker E, Renz J: The synthesis of a series of pharmacologically interesting $\mathrm{N}$-substituted derivatives of 3mercaptophenothiazines. J Helvetica Chimica Acta 41:1072-1108, 1958.

177. Spengler G, Takács D, Horváth A, Riedl Z, Hajós G, Amaral L and Molnár J. Multidrug resistance reversing activity of newly developed phenothiazines on P-glycoprotein (ABCB1)-related resistance of mouse T-lymphoma cells. Anticancer Res 34(4):1737-1741, 2014.

178. Takács D, Egyed O, Drahos L, Szabó P, Jemnitz K, Szabó M, Veres Z, Visy J, Molnár J, Riedl Z, Hajós G: Synthesis and pharmacological investigation of new N-hydroxyalkyl-2-aminophenothiazines exhibiting marked MDR inhibitory effect. Bioorg Med Chem 21(13):3760-3779, 2013.

179. Cornwell MM, Pastan I, Gottesman MM: Certain calcium channel blockers bind specifically to multidrug-resistant human $\mathrm{KB}$ carcinoma membrane vesicles and inhibit drug binding to $\mathrm{P}$ glycoprotein. J of Biol Chem. 262(5):2166-2170, 1987.

180. Chou TC and Martin N: CompuSyn for Drug Combinations: PC Software and User's Guide: A Computer Program for Quantitation of Synergism and Antagonism in Drug Combinations, and the Determination of $\mathrm{IC}_{50}$ and $\mathrm{ED}_{50}$ and $\mathrm{LD}_{50}$ Values, ComboSyn Inc, Paramus (NJ), 2005. 
181. Zeino M, Saeed MEM, Kadioglu O, Efferth T: The ability of molecular docking to unravel the controversy and challenges related to P-glycoprotein-a well-known, yet poorly understood drug transporter. Invest New Drugs 32(4):618-625, 2014.

182. Zhao Q Zeino, M, Eichhorn T, Hermann J, Müller R and Efferth T: Molecular docking studies of myxobacterial disorazoles and tubulysins to tubulin. J of Biosci Med 3:31-43, 2013.

183. Pérez-Herrero E, Fernández-Medarde A: Advanced targeted therapies in cancer: Drug nanocarriers, the future of chemotherapy. Eur J Pharm Biopharm. 93:52-79, 2015.

184. Hanahan D, Weinberg RA: Hallmarks of cancer: the next generation. Cell. 144(5): 646-74, 2011.

185. Pollock PM, Meltzer PS. Lucky draw in the gene raffle. Nature. 417(6892):906-907, 2002.

186. Zong D, Zielinska-Chomej K, Juntti T, Mörk B, Lewensohn R, Haag P, Viktorsson K: Harnessing the lysosome-dependent antitumor activity of phenothiazines in human small cell lung cancer. Cell Death Dis. 13(5):1111, 2014.

187. Mu J, Xu H, Yang Y, Huang W, Xiao J, Li M, Tan Z, Ding Q, Zhang L, Lu J, Wu X, Liu Y: Thioridazine, an antipsychotic drug, elicits potent antitumor effects in gastric cancer. Oncol Rep. 31(5):2107-2114, 2014.

188. Gutierrez A, Pan L, Groen RW, Baleydier F, Kentsis A, Marineau J, Grebliunaite R, Kozakewich E, Reed C, Pflumio F, Poglio S, Uzan B, Clemons P, VerPlank L, An F, Burbank J, Norton S, Tolliday N, Steen H, Weng AP, Yuan H, Bradner JE, Mitsiades C, Look AT, Aster JC: Phenothiazines induce PP2A-mediated apoptosis in T-cell acute lymphoblastic leukemia. J Clin Invest. 124(2):644-655, 2014.

189. Amaral L, Spengler G, Martins A, Armada A, Handzlik J, Kiec-Kononowicz K, Molnar J: Inhibitors of bacterial efflux pumps that also inhibit efflux pumps of cancer cells. Anticancer Res. 32(7):2947-2957, 2012.

190. Jaszczyszyn A, Gasiorowski K, Swiatek P, Malinka W, Cieslik-Boczula K, Petrus J, CzarnikMatusewicz B: Chemical structure of phenothiazines and their biological activity. Pharmacol Rep 64(1):16-23, 2012.

191. McConathy J, Owens MJ. Stereochemistry in Drug Action. Prim Care Companion J Clin Psychiatry. 5(2):70-73, 2003.

192. Lehn JM: Supramolecular Chemistry: Concepts and Perspectives. VHC Verlagsgesellschaft mbH. Weinheim. Germany. p. 190, 1995.

193. Svendsen CN, Froimowitz M, Hrbek C, Campbell A, Kula N, Baldessarini RJ, Cohen BM, Babb S, Teicher MH, Bird ED: Receptor affinity, neurochemistry and behavioral characteristics of the enantiomers of thioridazine: evidence for different stereoselectivities at D1 and D2 receptors in rat brain. Neuropharmacology 27(11):1117-1124. 1988.

194. Jortani SA, Valentour JC and Poklis A: Thioridazine enantiomers in human tissues. Forensic Sci Int. 64(2-3):165-170, 1994. 
195. Baumann P, Zullino DF, Eap CB: Enantiomers' potential in psychopharmacology-a critical analysis with special emphasis on the antidepressant escitalopram. Eur Neuropsychopharmacol. 12(5):433-444, 2002.

196. Ariens EJ: Stereochemistry, a basis for sophisticated nonsense in pharmakinetics and clinical pharmacology. Eur J Clin Pharmacol. 26(6):663-668, 1984.

197. Gruber A, Peterson C, Reizenstein P: D-verapamil and Lverapamil are equally effective in increasing vincristine accumulation in leukemic cells in vitro. Int J Cancer 41(2):224-226, 1988.

198. Kang S, Dong SM, Kim BR, Park MS, Trink B, Byun HJ, Rho SB: Thioridazine induces apoptosis by targeting the PI3K/Akt/mTOR pathway in cervical and endometrial cancer cells. Apoptosis 17(9):989-997, 2012.

199. Szabó D, Molnár J: The role of stereoselectivity of chemosensitizers in the reversal of multidrug resistance of mouse lymphoma cells. Anticancer Res. 18(4C):3039-3044, 1998. 


\section{ACKNOWLEDGMENTS}

I would like to express my deep and sincere gratitude to my supervisor, Prof. Dr. József

Molnár. He raised my interest in the experimental work, and gave me the pleasure of success. He understood my clinical problems and helped me to put them into a laboratory setting, and to find solutions. Through his open-mindedness, he has provided me with excellent support.

I would also like to express my grateful thanks to Prof. Dr. Endre Varga and Prof. Dr. Aurél János Simonka, present and past chairs of the Department of Traumatology, who ensured the conditions for my research work beside my clinical work.

I would further like to express my sincere gratitude to Dr. Katalin Burián and Prof. Dr. Yvette Mándi, present and past chairs of the Department of Medical Microbiology and Immunobiology, for providing me with the possibility to work at the department.

My special thanks are due to Dr. Gabriella Spengler, Mrs. Anikó Vigyikánné Váradi, Dr. Ana Martins and Prof. Dr. Leonard Amaral at the Department of Medical Microbiology and Immunobiology. I wish to thank them for all their help and support and for the interest they have shown.

I am likewise grateful to Dr. István Gárgyán and Dr. Gábor Süveges, senior consultants, for their support in my clinical work.

I would like to thank Dr. Imre Ocsovszki for performing the flow-cytometric measurements.

I feel a deep sense of gratitude to my wife and my family for always being so ready to help.

I express my thanks to all my co-workers, colleagues and staff members at the Departments of Microbiology and Traumatology, for creating a supportive and pleasant working environment.

I dedicate my thesis to my patients. 


\section{FINANCIAL SUPPORT}

The work on which this thesis was based was supported by the following organizations and grants:

- TÁMOP 4.2.4.B/2-11-1-2012-0001 (Campus Hungary Programme)

- TÁMOP 4.2.2.A-11/1/KONV-2012-0035

- Szeged Foundation for Cancer Research 


\section{APPENDIX}

Annex 1. Chemical structures of the steroid derivatives: 1: 20- $N$-( $N$-BOC-L-alanyl)aminopregna-5,16-dien-3 3 -ol

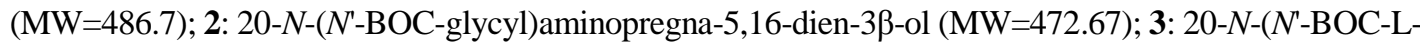

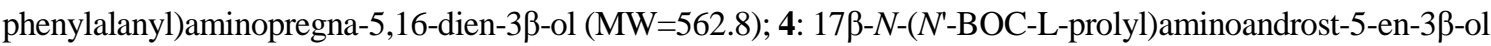

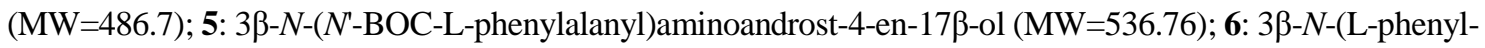

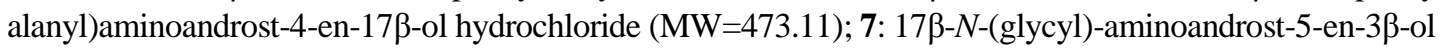

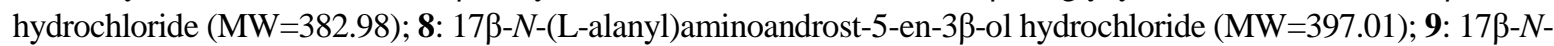

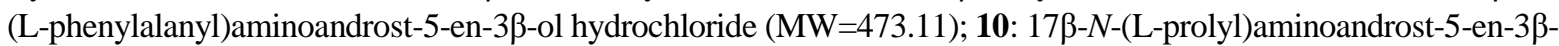

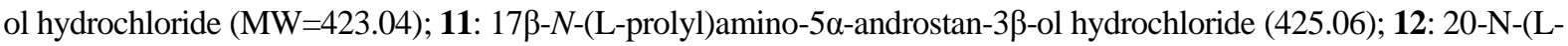
prolyl)aminopregna-5,16-dien-3 $\beta$-ol hydrochloride (MW=449.09); 13: $16-N$ - $(n$-propyl)- $N$-acetylaminomethylandrost-

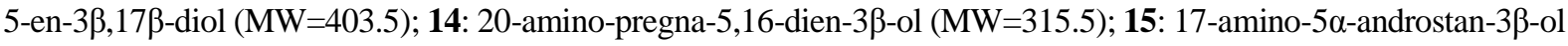

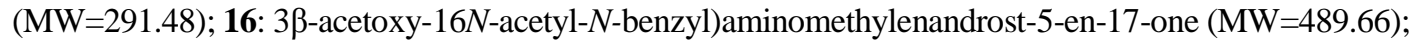

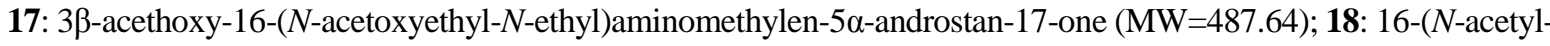

$N$-benzyl)aminomethylen-5 $\alpha$-androstane-3 $\beta, 17 \beta$-diol (MW=451.65); 19: $3 \beta$-acetoxy-16E-( $N$-acetyl- $N$ benzyl)aminomethylen-5 $\alpha$-androstan-17ß-ol (MW=493.69); 20: 16-( $N$-ethyl, $N-p$ -

sulphonylamidophenyl)aminomethylene-3-methoxyestra-1,3,5(10)-trien-17-one (MW=504.7); 21: 16,17[d]-2'aminopyrimidino-3-methoxyestra-1,3,5(10)-triene (MW=335.45); 22: 3-cyclopentyloxy-16-hydroxymethylen-estra-

1,3,5(10)-trien-17-one ( $\mathrm{MW}=366.5$ ); 23: $N$-BOC-L-isoleucine-Opcp (MW=477.68); where $\mathrm{BOC}$ is tertbutyloxycarbonyl and Pcp is pentachlorophenyl ester.

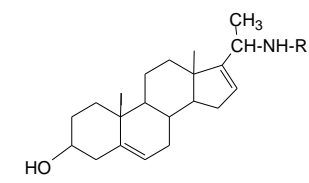

$\mathrm{R}$

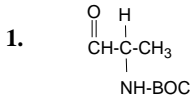

2. $\stackrel{\mathrm{O}}{\mathrm{C}-\mathrm{CH}_{2}-\mathrm{NH}-\mathrm{BOC}}$

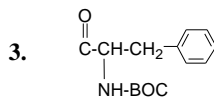

12. $\stackrel{\mathrm{II}}{\mathrm{C}}-\overbrace{\mathrm{H}^{+}}$

14.

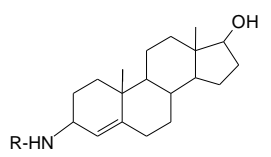

$\mathrm{R}$

5.

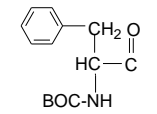

6.<smiles>[NH3+]C(C=O)Cc1ccccc1</smiles>

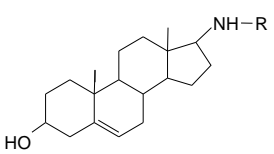

R

4. $\stackrel{C}{\mathrm{C}}-\prod_{\mathrm{N}^{1}}$

7. $\stackrel{\mathrm{O}}{\mathrm{C}-\mathrm{CH}_{2}-\mathrm{NH}_{+}} \mathrm{Cl}^{-}$

8. $\stackrel{\mathrm{OI}}{\mathrm{C}-\mathrm{C}-\mathrm{CH}_{3}}$

$\stackrel{\mathrm{NH}_{3}}{+} \mathrm{Cl}$

9.

I.

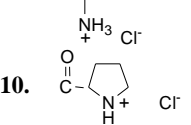

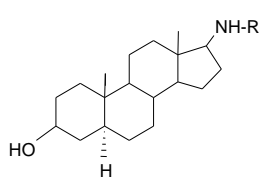

$\mathrm{R}$

11. $\stackrel{\mathrm{C}}{\mathrm{C}-\overbrace{\mathrm{N}^{+}}} \mathrm{Cl}$

15. $H$
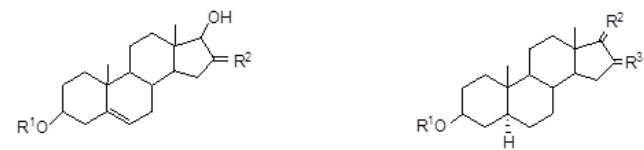

$\mathrm{R}^{1} \quad \mathrm{R}^{2}$

$\begin{array}{lll}R^{1} & R^{2} & R^{3}\end{array}$

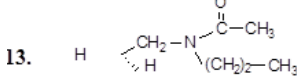

17. $\mathrm{H}_{3} \mathrm{C}-\mathrm{C}^{\prime \prime}-\mathrm{O}$

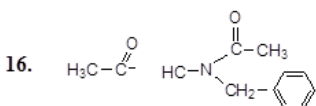

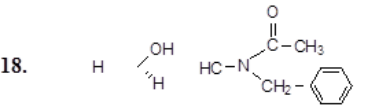

19. $\mathrm{H}_{3} \mathrm{C}-\mathrm{C}^{\circ}-\stackrel{\mathrm{OH}}{\mathrm{O}} \stackrel{\mathrm{H}}{\mathrm{C}} \stackrel{\mathrm{O}}{\mathrm{C}}$
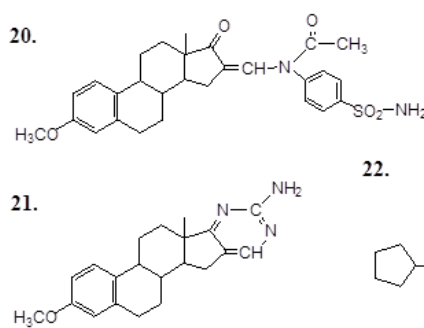

2

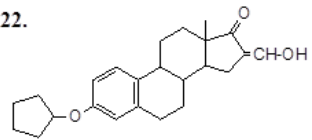

23.

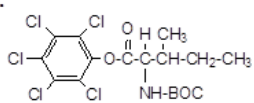


Annex 2. Enantiomers of thioridazine<smiles>CSc1ccc2c(c1)N(CC[C@H]1CCCCN1C)c1ccccc1Sc1ccccc1N2CC[C@H]1CCCCN1C</smiles>

Annex 3. Structures of $N$-hydroxyalkyl-2-aminophenothiazines (1a-o, 2, 3). Commonly, $\mathrm{R}^{\prime}$ is $\mathrm{OCH}_{3}$, except in 1e, where $\mathrm{R}^{\prime}$ is morpholine.

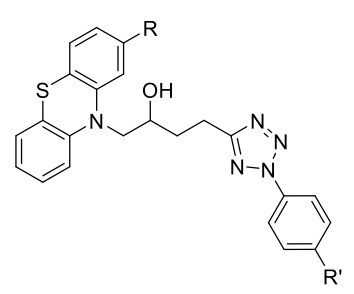

1a-o

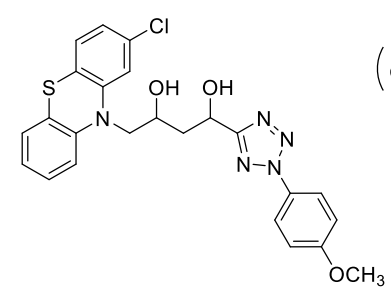

2

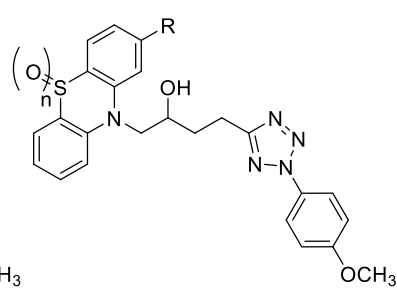

$3 a-j$

\begin{tabular}{|c|c|c|c|}
\hline 1 & $\mathbf{R}$ & 1 & $\mathbf{R}$ \\
\hline $\mathbf{a}$ & $\mathrm{H}$ & $\mathbf{h}$ & \\
\hline b & $\mathrm{Cl}$ & i & \\
\hline c & & $\mathbf{j}$ & \\
\hline d & & $\mathbf{k}$ & \\
\hline e & $\mathrm{H}$ & I & \\
\hline $\mathbf{f}$ & & $\mathbf{m}$ & \\
\hline $\mathbf{g}$ & & $\mathbf{n}$ & \\
\hline & & $\mathbf{0}$ & \\
\hline
\end{tabular}

\begin{tabular}{|c|c|c|}
\hline $\mathbf{3}$ & $\mathbf{n}$ & $\mathbf{R}$ \\
\hline $\mathbf{a}$ & 1 & $\mathrm{H}$ \\
\hline $\mathbf{b}$ & 1 & $\mathrm{Cl}$ \\
\hline $\mathbf{c}$ & 1 & \\
\hline $\mathbf{d}$ & 1 & \\
\hline $\mathbf{e}$ & 1 & $\mathrm{~N}-$ \\
\hline $\mathbf{f}$ & 2 & $\mathrm{~N}-$ \\
\hline $\mathbf{g}$ & 2 & $\mathrm{Cl}$ \\
\hline $\mathbf{h}$ & 2 & $\mathrm{O}^{\mathrm{N}-}$ \\
\hline $\mathbf{i}$ & 2 & \\
\hline $\mathbf{j}$ & 2 & $\mathrm{~N}-$ \\
\hline
\end{tabular}


XV. PUBLICATIONS 